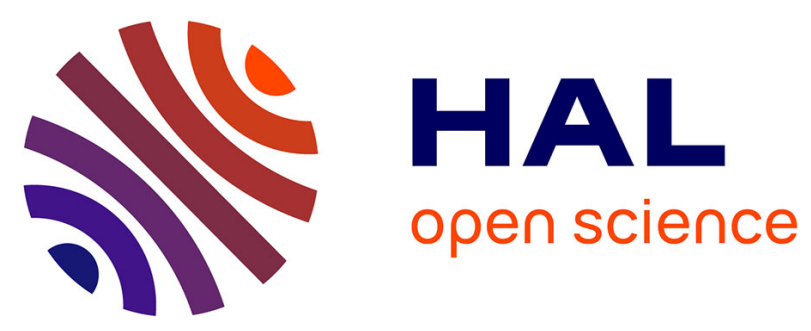

\title{
Outlet temperatures of a slinky-type Horizontal Ground Heat Exchanger with the atmosphere-soil interaction
}

\author{
Fujiao Tang, Hossein Nowamooz
}

\section{To cite this version:}

Fujiao Tang, Hossein Nowamooz. Outlet temperatures of a slinky-type Horizontal Ground Heat Exchanger with the atmosphere-soil interaction. Renewable Energy, 2020, 146, pp.705 - 718. 10.1016/j.renene.2019.07.029 . hal-03487359

\section{HAL Id: hal-03487359 \\ https://hal.science/hal-03487359}

Submitted on 20 Dec 2021

HAL is a multi-disciplinary open access archive for the deposit and dissemination of scientific research documents, whether they are published or not. The documents may come from teaching and research institutions in France or abroad, or from public or private research centers.
L'archive ouverte pluridisciplinaire HAL, est destinée au dépôt et à la diffusion de documents scientifiques de niveau recherche, publiés ou non, émanant des établissements d'enseignement et de recherche français ou étrangers, des laboratoires publics ou privés.

\section{다)(1) $(5$}

Distributed under a Creative Commons Attribution - NonCommercial| 4.0 International 
1 Outlet temperatures of a slinky-type Horizontal Ground Heat

2

\section{Exchanger with the atmosphere-soil interaction}

3

4

5

6

7

8

10 ICUBE, UMR 7357, CNRS, INSA de Strasbourg, 24 boulevard de la Victoire,

1167084 Strasbourg

12

13

14

15

16

17

18

19

$20 *$ Corresponding author

21 Email address:

22 fujiao.tang@insa-strasbourg.fr (Fujiao Tang) 


\section{$1 \quad$ Highlights}

2 - A numerical framework considering the atmosphere-soil interaction was constructed.

3 - The performance of a slinky-type Horizontal Ground Heat Exchanger was evaluated.

4 - The land surface temperature and heat flux were affected during the heating period.

5 - Non-consideration of the atmosphere-soil interaction led to higher outlet temperatures.

6 - The overestimation of the outlet temperature decreased as the installation depth increased.

7

9

10

11

12

13

14

15

16

17

18

19

20

21

22

23

24

25

26 


\section{Abstract}

2 Generally, a Horizontal Ground Heat Exchanger (HGHE) is installed in shallow depths, which

3 can influence the land surface temperature during its operation period, especially when a high

4 heat demand is required. Consequently, the existing methods of using time-varying land

5 surface temperatures are not sufficient for the HGHE simulations. In this paper, a numerical

6 framework considering the atmosphere-soil-HGHE interaction was proposed and validated.

7 The outlet temperatures of a slinky-type HGHE installed in a multi-layered soil field were

8 then investigated under the heating scenario by considering the local meteorological and

9 geological conditions. The results showed that the operation of the HGHE affected obviously

10 the land surface temperature and the ground heat flux. The increase of the installation depth

11 from 0.5 to $2 \mathrm{~m}$ increased the outlet temperatures. However, this increase was insignificant

12 when the installation depth increased from 0.5 to $1 \mathrm{~m}$. It was further identified that the non-

13 consideration of the atmosphere-soil interaction overestimated the annual fluid outlet

14 temperature in the heating scenario, and this overestimation decreased from $47.99 \%$ to

$1517.16 \%$ as the installation depth increased from 0.5 to $2 \mathrm{~m}$. In conclusion, it is necessary to 16 consider the atmosphere-soil interaction to predict precisely the outlet temperatures of a 17 shallow HGHE.

18 Keywords

19 Horizontal Ground Heat Exchanger; Numerical modeling; Outlet temperatures; Land surface 20 energy/water balance; Installation depth. 


\begin{tabular}{|c|c|c|c|}
\hline \multicolumn{2}{|c|}{ Nomenclature } & \multirow{2}{*}{$\begin{array}{l}S_{e} \\
S_{r}\end{array}$} & \multirow{2}{*}{$\begin{array}{l}\text { relative saturation of soil } \\
\text { saturation of soil }\end{array}$} \\
\hline$A$ & U-pipe cross-sectional area, $\mathrm{m}^{2}$ & & \\
\hline$a_{l}$ & surface albedo & $t$ & time, $\mathrm{s}$ \\
\hline$c_{c}$ & cloud cover & $T$ & temperature, ${ }^{\circ} \mathrm{C}$ or $\mathrm{K}$ \\
\hline$C_{p}$ & specific heat capacity, $\mathrm{Jkg}^{-1} \mathrm{~K}^{-1}$ & $T_{\text {in }}$ & inlet temperature, ${ }^{\circ} \mathrm{C}$ \\
\hline$C_{v}$ & volumetric heat capacity, $\mathrm{Jm}^{-3} \mathrm{~K}^{-1}$ & $T_{\text {out }}$ & outlet temperature, ${ }^{\circ} \mathrm{C}$ \\
\hline$d$ & displacement height, $\mathrm{m}$ & $T_{s}$ & land surface temperature, $\mathrm{K}$ \\
\hline$D$ & elevation head, $\mathrm{m}$ & $T_{\text {sky }}$ & sky temperature, $\mathrm{K}$ \\
\hline$e_{a}$ & actual vapor pressure, $\mathrm{kPa}$ & $u$ & velocity, $\mathrm{ms}^{-1}$ \\
\hline$e_{s}$ & saturation vapor pressure, $\mathrm{kPa}$ & $u_{\text {wind }}$ & wind speed, $\mathrm{ms}^{-1}$ \\
\hline E & $\begin{array}{l}\text { actual evaporation on the soil } \\
\text { surface, } \mathrm{mms}^{-1}\end{array}$ & $W_{i}$ & infiltration, $\mathrm{mms}^{-1}$ \\
\hline$E_{p}$ & $\begin{array}{l}\text { evaporation potential, } \mathrm{kgm}^{-2} \mathrm{~s}^{-1} \text { or } \\
\mathrm{mms}^{-1}\end{array}$ & $W_{r}$ & water run off, $\mathrm{mms}^{-1}$ \\
\hline$d_{h}$ & inner diameter of the U-pipe, $m$ & $x_{s}$ & gravimetric sand content \\
\hline$f_{D}$ & Darcy friction factor & $Z$ & U-pipe inner perimeter, $\mathrm{m}$ \\
\hline$G$ & $\begin{array}{l}\text { total heat flux through land surface, } \\
\mathrm{Wm}^{-2}\end{array}$ & $z_{m}$ & $\begin{array}{l}\text { height for measuring } \\
\text { meteorological conditions, } \mathrm{m}\end{array}$ \\
\hline$h_{c}$ & vegetation height, m & $z_{o h}$ & water vapor roughness length, m \\
\hline $\begin{array}{l}h_{\text {int }} \\
H\end{array}$ & $\begin{array}{l}\text { heat transfer coefficient, } \mathrm{Wm}^{-2} \mathrm{~K}^{-1} \\
\text { sensible heat flux, } \mathrm{Wm}^{-2}\end{array}$ & zom & momentum roughness length, m \\
\hline$H_{k}$ & kinetic head, $\mathrm{m}$ & Greek symb & bols \\
\hline$H_{p}$ & water potential or suction head, m & $\Delta$ & $\begin{array}{l}\text { slope of the saturation vapor } \\
\text { pressure curve, } \mathrm{kPaK}^{-1}\end{array}$ \\
\hline$k$ & thermal conductivity, $\mathrm{Wm}^{-1} \mathrm{~K}^{-1}$ & $\alpha$ & independent parameter, $\mathrm{m}^{-1}$ \\
\hline$k_{r}$ & relative hydraulic conductivity & $\gamma$ & psychrometric constant, $\mathrm{kPaK}^{-1}$ \\
\hline$K$ & hydraulic conductivity, $\mathrm{ms}^{-1}$ & $\gamma_{d}$ & soil dry unit weights, $\mathrm{kNm}^{-3}$ \\
\hline$l$ & pore connectivity parameter & $\gamma_{s}$ & soil specific unit weights, $\mathrm{kNm}^{-3}$ \\
\hline$L$ & $\begin{array}{l}\text { latent heat of vaporization for } \\
\text { water, } \mathrm{Jkg}^{-1}\end{array}$ & $\varepsilon$ & soil surface emissivity \\
\hline$L A I$ & leaf area index & $\theta$ & volumetric water content \\
\hline$n$ & independent parameter & $\kappa$ & von Karman constant \\
\hline$P$ & rainfall rate, $\mathrm{mms}^{-1}$ & $\rho$ & density, $\mathrm{kgm}^{-3}$ \\
\hline$P_{a t}$ & atmospheric pressure, $\mathrm{Pa}$ & $\sigma$ & $\begin{array}{l}\text { Stephan-Boltzman constant, } \mathrm{Wm}^{-} \\
{ }^{2} \mathrm{~K}^{-4}\end{array}$ \\
\hline$Q_{s}$ & soil heat source, $\mathrm{Wm}^{-3}$ & $\psi$ & specific moisture capacity, $\mathrm{m}^{-1}$ \\
\hline$Q_{\text {wall }}$ & heat from the surrounding, $\mathrm{Wm}^{-1}$ & & \\
\hline$r_{1}$ & $\begin{array}{l}\text { stomatal resistance of a single leaf, } \\
\mathrm{sm}^{-1}\end{array}$ & Subscripts & \\
\hline$r_{a}$ & $\begin{array}{l}\text { aerodynamic resistance to heat } \\
\text { transfer, } \mathrm{sm}^{-1}\end{array}$ & $a$ & air \\
\hline$r_{c}$ & crop canopy resistance, $\mathrm{sm}^{-1}$ & $f$ & carrying fluid \\
\hline$r_{m w}$ & $\begin{array}{l}\text { molecular weight of water vapor to } \\
\text { dry air }\end{array}$ & $i-p$ & inner pipe wall \\
\hline$R_{a}$ & income longwave radiation, $\mathrm{Wm}^{-2}$ & $r$ & residual \\
\hline$R_{n}$ & net radiation, $\mathrm{Wm}^{-2}$ & $s$ & soil \\
\hline$R_{s}$ & shortwave radiation, $\mathrm{Wm}^{-2}$ & sat & saturated \\
\hline$R H$ & air humidity, $\%$ & $w$ & water \\
\hline
\end{tabular}




\section{$1 \quad 1$ Introduction}

2 Renewable energy is continuing to gain importance due to the fact that traditional energy

3 sources are not unlimited in the long run, especially for an epoch with increasing energy

4 demand. Moreover, environmental risks such as air pollution, regional acidification and

5 climate change [1] emerge gradually by consuming fossil fuels. Sangi and Müller [2] report that the European Union has set the goal to reduce its $\mathrm{CO}_{2}$ emission by $20 \%$ till 2020 compared to the year 2007 and renewable energy is crucial for this aim to be achieved.

8 Shallow geothermal energy is among the many sources of renewable energy, and it can be

9 easily accessed all around the world. The shallow geothermal energy system has an 10 approximate lifespan of 40-50 years and is regarded as a semi-permanent energy system [3].

11 Generally, open and closed heat exchangers are available for the exploitation of shallow geothermal energy [4], which are then served as low-potential sources of thermal energy for heat pumps [5]. Horizontal Ground Heat Exchanger (HGHE) is one of those closed loop heat exchangers. Compared to Vertical Ground Heat Exchanger (VGHE), it is more cost effective

although it requires more installation space [6]. The costs can be further reduced by using a slinky-type HGHE [7], which enables HGHE to be an appealing technology for residential and small non-residential applications [8]. However, due to the shallow installation depth (conventionally between 1.0 and $2.0 \mathrm{~m}$ ) [9,10], it is more sensitive to the meteorological condition than VGHE.

In HGHE engineering, it is necessary to estimate accurately the performance of a given HGHE in the design stage [11]. Numerical modeling is the most popular method since it is comprehensive and can reduce the initial capital investment. Till now, several numerical simulations have been conducted to investigate the performance of a HGHE at different conditions. By using CFD code Fluent, Congedo et al. [12] find that increasing the installation 
1 depth of a HGHE from 1.5 to $2.5 \mathrm{~m}$ does not play an important role on the system

2 performance. However, they conclude that the ground thermal conductivity is the most

3 important parameter for the heat transfer performance of their system. By developing an in-

4 house numerical simulation program, Gan [13] finds that the soil freezing can generally

5 increase the heat extraction rate of a HGHE. He observes especially that when the soil

6 freezing happens in the vicinity of the pipe, the heat extraction rate increases $1.7 \%$ for the

7 carrying fluid temperature of $-1{ }^{\circ} \mathrm{C}$. By using a transient three-dimensional finite volume

8 model in ANSYS Fluent, Al-Ameen et al. [8] find that adopting mill-scale copper slag instead

9 of Leighton buzzard sand as a backfill material increases the HGHE performance. By using

10 the finite volume method, Habibi and Hakkaki-Fard [10] conclude that the slinky-type HGHE

11 performs $75 \%$ and $9 \%$ better than the linear and spiral HGHEs, respectively. By using Midas

12 NFX numerical program, Kim et al. [11] find that the pipe diameter influences negligibly the

13 heat exchange rate of the HGHE. By using COMSOL Multiphysics simulations for a spiral

14 HGHE, Go et al. [14] conclude that the increase of the flow rate generally has a positive

15 influence on the HGHE performance. However, the total efficiency will decrease in inverse

16 proportion to the flow rate if the coil pitch becomes too narrow.

17 Despite the popularity of the numerical simulations in HGHE engineering, there are some

18 points often neglected or simplified in many numerical investigations.

19 Due to the complex atmosphere-soil interaction, time-varying land surface temperatures are

20 often considered in the numerical simulations. For example, the atmosphere temperature is

21 conventionally applied as a surface boundary [8,10,14-21]. Wu et al. [22] have experimentally

22 investigated a slinky-type HGHE in an $80 \mathrm{~m}$ long by $20 \mathrm{~m}$ wide paddock area at a depth of

23 around $1.2 \mathrm{~m}$ below the ground surface at Talbot Cottage, Drayton St Leonard site,

24 Oxfordshire, UK. They discover that the ground surface temperature is higher when no heat 
1 exchanger is installed, proving that the operation of the HGHE has influenced the land surface

2 temperature. This means that time-varying land surface temperatures (such as atmosphere

3 temperatures) might not be sufficient to estimate the HGHE performance. This point is often

4 absent in the numerical simulations.

5 By measuring the soil thermal conductivity at five sites in Midwestern USA at the depth of

$6 \quad 1.2 \mathrm{~m}$, Naylor et al. [23] find that the soil moisture fluctuations result in a very significant

7 variation of the soil thermal conductivity. Gan [24] concludes in his numerical simulations

8 that the maximum differences of heat transfer through a HGHE between the models with and

9 without moisture transfer are $24 \%, 17 \%$ and $18 \%$ in clay sand, loamy sand and sandy soils,

10 respectively. Therefore, the consideration of the hydrothermal transfer in shallow zones is

11 necessary for the design of HGHE, often neglected in the numerical simulations.

12 A slinky-type HGHE has a good performance and it is popular in real practice [2,10,25].

13 Linear-type and spiral-type HGHEs are often studied in the numerical simulations as their 14 geometries are easier to be constructed [15]. However, numerical studies on slinky-type 15 HGHE are limited due to its complex geometry.

The main objective of this investigation is to construct a robust numerical simulation

17 framework to evaluate the HGHE performance in field conditions by considering energy and 18 water balance on the land surface. This investigation also aims to visualize how the HGHE 19 influences the land surface temperature and the heat flux through the land surface, rarely 20 studied so far. Moreover, the investigation has compared the numerical simulation results 21 under two different surface boundary conditions (with/without considering atmosphere-soil 22 interaction), which helps to identify the reliability of the traditional method by setting time23 varying temperature as land surface boundary.

24 In this context, a validated finite element model established in COMSOL is used to estimate 
1 the performance of a HGHE installed in a multi-layered soil field. The above-mentioned

2 neglected points such as land surface energy/water balance, hydrothermal fluctuations and a

3 slinky-type HGHE are addressed in this numerical framework.

\section{$4 \quad 2$ Governing Equations}

5 Fig. 1 shows a schematic diagram of the concerning phenomenon in HGHE engineering. The necessary governing equations considering the atmosphere-soil-HGHE interaction are constituted of 4 parts: a) the soil surface energy balance; b) the soil surface water balance; c)

8 the hydrothermal transfer in subsurface soil and d) the heat transfer in pipe.

Fig. 1 Schematic diagram for the considered mechanism of the energy and water transfer in

\subsection{Soil surface energy balance}

Energy balance on the land surface is given as [26]:

$$
R_{n}+H-L E-G=0
$$

where $R_{n}$ is the net radiation heat flux $\left(\mathrm{Wm}^{-2}\right), H$ is the sensible heat flux $\left(\mathrm{Wm}^{-2}\right), L E$ is the latent heat flux $\left(\mathrm{Wm}^{-2}\right), G$ is the ground heat flux $\left(\mathrm{Wm}^{-2}\right)$. It should be noted that the net

17 radiation and the sensitive heat flux have both positive and negative values while the latent 
1 heat flux has only positive values. The ground heat flux indicates the total heat flux flow

2 through the land surface. A positive value represents the heat flux into the ground. On the 3 contrary, a negative value represents the heat flux out from the ground. To calculate the 4 ground heat flux, it is necessary to obtain the net radiation heat flux, the sensitive heat flux 5 and the latent heat flux.

6 At first, net radiation is the difference between the total incoming and outgoing radiations:

$$
R_{n}=\left(1-a_{l}\right) R_{s}+\left(R_{a}-\varepsilon \sigma T_{s}^{4}\right)
$$

where $a_{l}$ is the surface albedo, $R_{s}$ is the shortwave radiation $\left(\mathrm{Wm}^{-2}\right), R_{a}$ is the incoming 9 longwave radiation $\left(\mathrm{Wm}^{-2}\right), \varepsilon \delta T_{s}^{4}$ is the outcoming longwave radiation $\left(\mathrm{Wm}^{-2}\right), \varepsilon$ is the soil surface emissivity, $\sigma$ is Stephan-Boltzman constant $\left(\mathrm{Wm}^{-2} \mathrm{~K}^{-4}\right), T_{s}$ is the soil temperature $(\mathrm{K})$.

11 The net long wave radiation can be obtained by:

$$
R_{a}-\varepsilon \sigma T_{s}^{4}=-\sigma \varepsilon\left(T_{s}^{4}-T_{s k y}^{4}\right)
$$

where sky temperature $T_{s k y}(\mathrm{~K})$ is decided by cloud cover $c_{c}$ and air temperature $T_{a}(\mathrm{~K})$ [27]:

$$
T_{s k y}^{4}=9.365574 \times 10^{-6}\left(1-c_{c}\right) T_{a}^{6}+c_{c}\left[\left(1-0.84 \cdot c_{c}\right)\left(0.527+0.161 \cdot \mathrm{e}^{8.45\left(1-\frac{273.15}{T_{a}}\right)}\right)+0.84 \cdot c_{c}\right] T_{a}^{4}
$$

Secondly, it is the sensible heat flux, which is the convective heat transfer between the ground surface and the ambient air [28], given as:

$$
H=\rho_{a} C_{p-a}\left(T_{a}-T_{s}\right) / r_{a}
$$

20 aerodynamic resistance to heat transfer $\left(\mathrm{sm}^{-1}\right)$.

21 The aerodynamic resistance is given as [29]: 


$$
r_{a}=\frac{\ln \left(\frac{z_{m}-d}{z_{o m}}\right) \cdot \ln \left(\frac{z_{m}-d}{z_{o h}}\right)}{\kappa^{2} u_{\text {wind }}}
$$

2 where $z_{m}$ is the height where the meteorological parameters are measured $(\mathrm{m}), d$ is the 3 displacement height (m), zom is the roughness length for momentum (m), $z_{o h}$ is the roughness 4 length for water vapor $(\mathrm{m}), \kappa$ is the von Karman constant, and $u_{\text {wind }}$ is the wind speed $\left(\mathrm{ms}^{-1}\right)$.

5 The displacement height is linear to the vegetation height $h_{c}(\mathrm{~m})$ :

$$
d=2 h_{c} / 3
$$

7 The roughness length for momentum transfer is calculated by:

$$
z_{\text {om }}=0.123 h_{c}
$$

9 The roughness length for vapor transfer is:

$$
z_{o h}=0.1 z_{o m}
$$

11 Finally, the latent heat flux is represented by $L E$, constituted by the latent heat vaporization of 12 water $L\left(\mathrm{Jkg}^{-1}\right)$ and the actual evaporation $E\left(\mathrm{mms}^{-1}\right)$. The actual evaporation can be obtained 13 by the following equation [30-33]:

$$
E=P \cdot\left[1+\left(E_{p} / P\right)^{-2}\right]^{-\frac{1}{2}}
$$

15 where $P$ is the rainfall rate $\left(\mathrm{mms}^{-1}\right), E_{p}$ is the evaporation potential $\left(\mathrm{kgm}^{-2} \mathrm{~s}^{-1}\right.$ or $\left.\mathrm{mms}^{-1}\right)$.

16 The evaporation potential is obtained by Penman-Monteith formulation [34]:

$$
E_{p}=\frac{1}{L}\left[\frac{\Delta \cdot R_{n}+\rho_{a} C_{p-a}\left(e_{s}-e_{a}\right) / r_{a}}{\Delta+\gamma\left(1+r_{c} / r_{a}\right)}\right]
$$

18 where $\Delta$ is the slope of the saturation vapor pressure curve $\left(\mathrm{kPaK}^{-1}\right), e_{s}$ is the saturation vapor 
1 pressure $(\mathrm{kPa}), e_{a}$ is the actual vapor pressure $(\mathrm{kPa}), \gamma$ is the psychrometric constant $\left(\mathrm{kPaK}^{-1}\right)$,

$2 \quad r_{c}$ is the crop canopy resistance $\left(\mathrm{sm}^{-1}\right)$.

3 The slope of the saturation vapor pressure is given by:

$$
\Delta=4098 e_{s} /\left(T_{a}-35.85\right)^{2}
$$

5 The saturation vapor pressure is related to air temperature $T_{a}(\mathrm{~K})$ :

$$
e_{s}=0.6108 \cdot \exp \left(17.27\left(T_{a}-273.15\right) /\left(T_{a}-35.85\right)\right)
$$

7 The actual vapor pressure is positive to air humidity $R H(\%)$ :

$$
e_{a}=R H \cdot e_{s} / 100
$$

9 The psychrometric constant is calculated by:

$$
\gamma=C_{p-a} \cdot P_{a t} /\left(L \cdot r_{m w}\right)
$$

11 where $P_{a t}$ is the atmospheric pressure $(\mathrm{Pa}), r_{m w}$ is the molecular weight of water vapor to dry 12 air.

13 The crop canopy resistance is:

$$
r_{c}=r_{1} /(0.5 \cdot L A I)
$$

15 where $r_{l}$ is the stomatal resistance of a single leaf $\left(\mathrm{sm}^{-1}\right), L A I$ is the leaf area index [26,35]:

16 (a) For clipped grass $\left(h_{c}=0.05-0.15 \mathrm{~m}\right)$ :

$$
L A I=24 \cdot h_{c}
$$

18 (b) For other crops:

$$
L A I=5.5+1.5 \ln \left(h_{c}\right)
$$




\section{$1 \quad 2.2$ Soil surface water balance}

2 The precipitation $(P)$ is the only water source, which is kept balanced with water run off $\left(W_{r}\right)$,

3 actual evaporation $(E)$, and infiltration $\left(W_{i}\right)$ through the land surface [36]. Therefore:

$$
P=W_{r}+E+W_{i}
$$

\section{$5 \quad 2.3$ Hydrothermal transfer in subsurface soil}

6 The Richards equation is used to calculate the hydraulic variation with space and time:

$$
\rho_{w} \cdot \psi \cdot \frac{\partial H_{p}}{\partial t}+\nabla \cdot\left[-K \cdot k_{r} \cdot \nabla \cdot \rho_{w} \cdot\left(H_{p}+D+H_{k}\right)\right]=0
$$

8 where $\rho_{w}$ is the water density $\left(\mathrm{kgm}^{-3}\right), \psi$ is the specific moisture capacity $\left(\mathrm{m}^{-1}\right), H_{p}$ is the

9 suction head $(\mathrm{m}), t$ is the time (s), $K$ is the hydraulic conductivity $\left(\mathrm{ms}^{-1}\right), k_{r}$ is the relative hydraulic conductivity, $D$ is the elevation head $(\mathrm{m}), H_{k}$ is the kinetic head (m). The kinetic

11 head is very small in the current investigation and it is therefore neglected.

Mualem equation [37] is used for obtaining relative hydraulic conductivity:

$$
k_{r}= \begin{cases}S_{e}^{l}\left[1-\left(1-S_{e}^{n /(n-1)}\right)^{1-1 / n}\right]^{2} & H_{p}<0 \\ 1 & H_{p} \geq 0\end{cases}
$$

where $S_{e}$ is the relative saturation of the soil, $l$ is the pore connectivity parameter, $n$ is a measure of the pore-size distribution. van Genuchten [38] equation is used for representing the relation between the suction and the relative saturation:

$$
S_{e}= \begin{cases}\frac{1}{\left[1+\left|\alpha H_{p}\right|^{n}\right]^{1-1 / n}} & H_{p}<0 \\ 1 & H_{p} \geq 0\end{cases}
$$

19 where $\alpha$ is related to the inverse of the air entry suction $\left(\mathrm{m}^{-1}\right)$. 
1 The approach proposed by Nowamooz et al. $[39,40]$ is used for the soil thermal conductivity:

$$
k_{s}=\left(0.443 x_{s}+0.081 \gamma_{d}\right) \frac{\left(4.4 x_{s}+0.4\right) S_{r}}{1+\left(4.4 x_{s}-0.6\right) \mathrm{S}_{r}}+0.087 x_{s}+0.019 \gamma_{d}
$$

3 where $x_{s}, \gamma_{d}$, and $S_{r}$ are the soil sand content, dry unit weight $\left(\mathrm{kNm}^{-3}\right)$ and saturation, 4 respectively.

5 The approach proposed by Tang and Nowamooz [41,42] is used to calculate the soil

6 volumetric heat capacity:

7

$$
C_{v-s}=\left(4.18-0.095 \gamma_{d}-0.3 x_{s}\right) \mathrm{S}_{r}+0.09 \gamma_{d}-0.2 x_{s}
$$

The energy conservation equation in the soil is given as:

$$
\rho_{s} C_{p-s} \frac{\partial T_{s}}{\partial t}=\nabla \cdot\left(k_{s} \nabla T_{s}\right)+\nabla \cdot\left(\rho_{w} C_{p-w} u_{w} T_{s}\right)+Q_{s}
$$

where $\rho_{s}$ is the soil density $\left(\mathrm{kgm}^{-3}\right), C_{p-s}$ is the soil heat capacity $\left(\mathrm{Jkg}^{-1} \mathrm{~K}^{-1}\right), T_{s}$ is the soil temperature $\left({ }^{\circ} \mathrm{C}\right), C_{p-w}$ is the water specific heat capacity $\left(\mathrm{Jkg}^{-1} \mathrm{~K}^{-1}\right), u_{w}$ is the water velocity in soil $\left(\mathrm{ms}^{-1}\right), Q_{s}$ is the soil heat source $\left(\mathrm{Wm}^{-3}\right)$.

The hydrothermal transfer equations in subsurface soil have been introduced in detail in our previous publication [42].

\subsection{Heat transfer in pipe}

The 1D heat transfer in the pipe includes its wall layer, its internal film, and the carrying incompressible fluid. The friction heat is kept in the energy balance equation although it has a negligible effect in the heat transfer of the pipe. The energy conservation equation is given as:

$$
A \rho_{f} C_{p-f} \frac{\partial T_{f}}{\partial t}+A \rho_{f} C_{p-f} u_{f} \cdot \nabla T_{f}=\nabla \cdot A k_{f} \nabla T_{f}+f_{D} \frac{\rho_{f} A}{2 d_{h}}\left|u_{f}\right| u_{f}{ }^{2}+Q_{w a l l}
$$

where $A$ is the pipe inner cross-sectional area $\left(\mathrm{m}^{2}\right), \rho_{f}$ is the fluid density $\left(\mathrm{kgm}^{-3}\right), C_{p-f}$ is the fluid specific heat capacity $\left(\mathrm{Jkg}^{-1} \mathrm{~K}^{-1}\right), T_{f}$ is the fluid temperature $\left({ }^{\circ} \mathrm{C}\right), u_{f}$ is the fluid flowing velocity $\left(\mathrm{ms}^{-1}\right), k_{f}$ is the fluid thermal conductivity $\left(\mathrm{Wm}^{-1} \mathrm{~K}^{-1}\right), f_{D}$ is the Darcy friction factor, 
$1 \quad d_{h}$ is the hydraulic diameter (m) and $Q_{\text {wall }}$ is the energy from the surrounding media $\left(\mathrm{Wm}^{-1}\right)$.

2 The energy from the surrounding media is given as:

$$
Q_{\text {wall }}=h_{\text {int }} \cdot Z \cdot\left(T_{i-p}-T_{f}\right)
$$

4 where $h_{\text {int }}$ is the film heat transfer coefficient $\left(\mathrm{Wm}^{-2} \mathrm{~K}^{-1}\right) . Z$ is the pipe inner perimeter $(\mathrm{m})$ and $5 \quad T_{i-p}$ is the inner pipe temperature $\left({ }^{\circ} \mathrm{C}\right)$.

\section{3. Validation of the proposed numerical framework}

7 The atmosphere-soil-HGHE interaction is considered in our numerical simulation framework.

8 To evaluate the capacity of the proposed model, the atmosphere-soil interaction (equations 1-

9 11) was firstly evaluated by using a local instrumented temperature probe [43]. Subsequently,

10 the soil-HGHE interaction (equations 11-13) was evaluated by an indoor experiment

11 conducted by Yoon et al. [44].

\subsection{Validation for the atmosphere-soil interaction}

A local site in Alsace region (France) was chosen for this validation since we have access to

14 the geological, metrological and hydraulic conditions of this field $[39,42,43]$. The soil at the top $20 \mathrm{~m}$ is constituted of 4 soils and 6 soil layers (Fig. 2): layer 1 with $0.1 \mathrm{~m}$ of clay loam; layer 2 with $1 \mathrm{~m}$ of sandy loam; layer 3 with $0.15 \mathrm{~m}$ of loam; layer 4 with $4.75 \mathrm{~m}$ of sandy

17 loam; layer 5 with $8 \mathrm{~m}$ of a second sandy loam and layer 6 with $6 \mathrm{~m}$ of loam. 


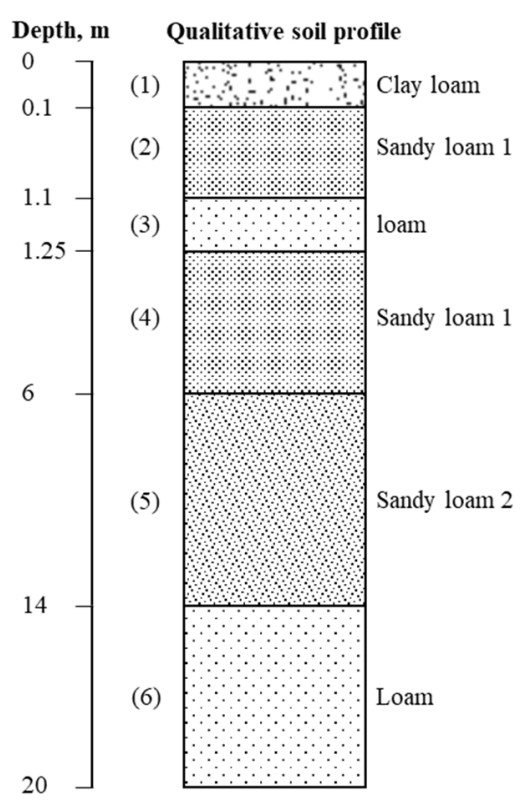

Fig. 2 Six soil layers at the investigated site.

3 A temperature probe was installed at a depth of $1.03 \mathrm{~m}$ on this site. To validate the capacity of

4 the model for the atmosphere-soil interaction, the model was run for three years without the

5 installation of the HGHE.

6 Table 1 and Table 2 present the parameters for the atmosphere-soil interaction (equations 1-

7 11). Table 1 presents the parameters for the soil surface energy balance and Table 2

8 summarizes the hydrothermal properties of the subsurface soils $[42,45]$.

Table 1 Parameters for the soil surface energy balance

\begin{tabular}{llll}
\hline Parameter & Description & Value & Unit \\
\hline$a_{l}$ & Albedo & 0.25 & - \\
$\varepsilon$ & Soil emissivity & 0.97 & - \\
$\sigma$ & Stephan-Boltzman constant & $5.67 \times 10^{-8}$ & $\mathrm{Wm}^{-2} \mathrm{~K}^{-4}$ \\
$\rho_{a}$ & Air density & 1.25 & $\mathrm{kgm}^{-3}$ \\
$C_{p-a}$ & Air specific heat capacity & $1.003 \times 10^{3}$ & $\mathrm{Jkg}^{-1} \mathrm{~K}^{-1}$ \\
$z_{m}$ & Height to collect the meteorological data & 2 & $\mathrm{~m}$ \\
$h_{c}$ & Grass height & 0.06 & $\mathrm{~m}$ \\
$\kappa$ & von Karman constant & 0.41 & - \\
$L$ & Latent heat of vaporization & 2.260 & $\mathrm{Jkg}$ \\
$P_{a t}$ & Atmospheric pressure & 102000 & $\mathrm{~Pa}$ \\
\hline
\end{tabular}




\begin{tabular}{llll}
\hline$r_{m w}$ & Molecular weight of water vapor to dry air & 0.622 & - \\
$r_{1}$ & Stomatal resistance of a single leaf & 100 & $\mathrm{sm}^{-1}$ \\
\hline
\end{tabular}

Table 2 Hydrothermal properties of the subsurface soils

\begin{tabular}{cccccccccc}
\hline Material & $K\left(\mathrm{~ms}^{-1}\right)$ & $l(-)$ & $\alpha\left(\mathrm{m}^{-1}\right)$ & $n(-)$ & $\theta_{s}(-)$ & $\theta_{r}(-)$ & $x_{s}(-)$ & $\gamma_{s}\left(\mathrm{kNm}^{-3}\right)$ & $\gamma_{d}\left(\mathrm{kNm}^{-3}\right)$ \\
\hline Clay loam & $1.53 \mathrm{E}-6$ & 0.5 & 1.99 & 1.22 & 0.50 & 0.03 & 0.35 & 27.0 & 13.5 \\
Sandy loam 1 & $1.78 \mathrm{E}-5$ & 0.5 & 2.60 & 1.52 & 0.39 & 0.02 & 0.80 & 26.2 & 16.0 \\
Loam & $2.19 \mathrm{E}-6$ & 0.5 & 2.35 & 1.38 & 0.47 & 0.02 & 0.50 & 26.8 & 14.2 \\
Sandy loam 2 & $1.45 \mathrm{E}-5$ & 0.5 & 2.48 & 1.50 & 0.40 & 0.02 & 0.60 & 26.7 & 16.0 \\
\hline
\end{tabular}

4 The ambient temperatures of the investigated site have been monitored during several years

$5 \quad[43,46]$. Based on the in-situ measurements, the following equation is used for approximating ambient temperature $[43,46]$ :

$$
\begin{aligned}
& T_{a}=13.4-9.43 \cdot \sin (2 \cdot \pi /(365 \times 24 \times 3600) \cdot t+4.63)+ \\
& (-3.52+2.1 \times \sin (2 \cdot \pi /(365 \times 24 \times 3600) \cdot t-1.25)) \cdot \sin (2 \cdot \pi /(24 \times 3600) \cdot \mathrm{t}+1)
\end{aligned}
$$

where $t$ is time (s). The comparison between the approximated and measured ambient temperatures from July 2014 to July 2017 is shown in Fig. 3:

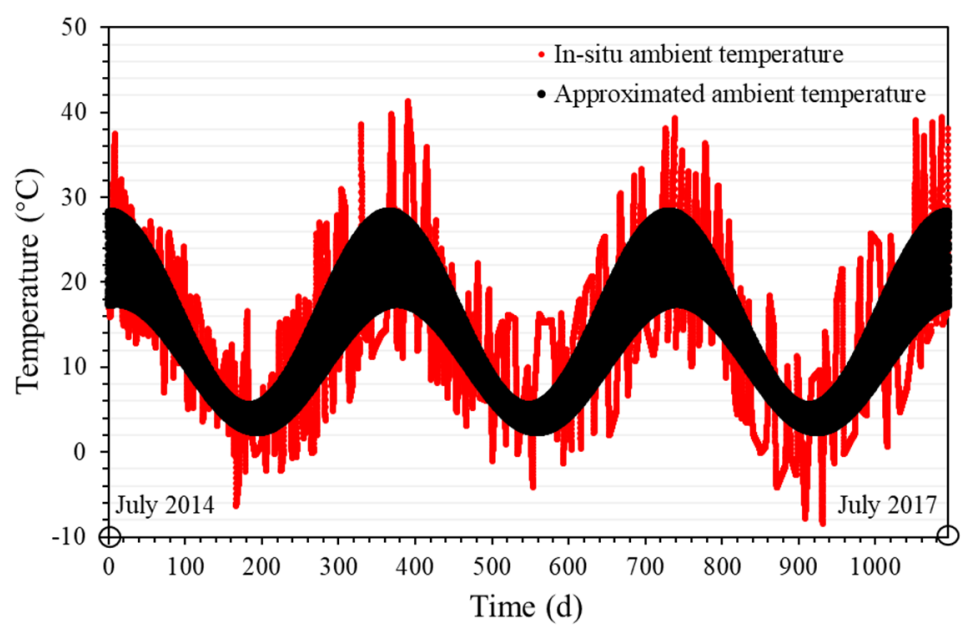

Fig. 3 Comparison between the approximated and measured ambient temperatures for a duration of 3 years from July 2014 to July 2017 [43,46].

Moreover, the local shortwave radiation is given as:

$$
R_{s}=130+80 \cdot \cos (2 \cdot \pi /(365 \times 3600 \times 24) \cdot t)
$$


1 At the site, there is no obvious seasonal fluctuation of cloud cover, wind speed, precipitation

2 and air humidity with time. Therefore, an average cloud cover of 0.41 , an average wind speed

3 of $2 \mathrm{~ms}^{-1}$, an average monthly precipitation of $55.7 \mathrm{~mm}$, and an average air humidity of $83 \%$

4 are applied in the numerical simulation model to capture the main meteorological condition of

5 the local site.

6 For the surface water balance, $20 \%$ of precipitation run off, and the other $80 \%$ participate into

7 evapotranspiration or infiltration.

8 Table 3 summarizes all the imposed hydrothermal boundary conditions in this part. The

9 temperature gradient at the bottom boundary is set $0.142 \mathrm{Km}^{-1}$ [47], and the extra water from

10 the precipitation is drained at the bottom boundary. The groundwater level is set constant at

11 the depth of $7.5 \mathrm{~m}$ in the whole year. No hydrothermal flow is imposed on the lateral

12 boundaries.

13 Table 3 Hydrothermal boundary conditions for the scenario with the atmosphere-soil interaction

\begin{tabular}{lll}
\hline Surface & Hydraulic condition, value (unit) & Thermal condition, value (unit) \\
\hline Top & Neumann, equation $5\left(\mathrm{~ms}^{-1}\right)$ & Neumann, equation $1\left(\mathrm{Wm}^{-2}\right)$ \\
Lateral & Adiabatic, - & Adiabatic, - \\
Bottom & $\begin{array}{l}\text { Dirichlet, model height }- \text { groundwater } \\
\text { level }(\mathrm{m})\end{array}$ & $\begin{array}{l}\text { Neumann, bottom temperature gradient } \times \\
\text { bottom soil thermal conductivity }\left(\mathrm{Wm}^{-2}\right)\end{array}$ \\
\hline
\end{tabular}

15

16 An equilibrium method is used to obtain the initial hydrothermal profiles [42,45]. Fig. 4

17 shows the suction and temperature profiles derived from this approach. 

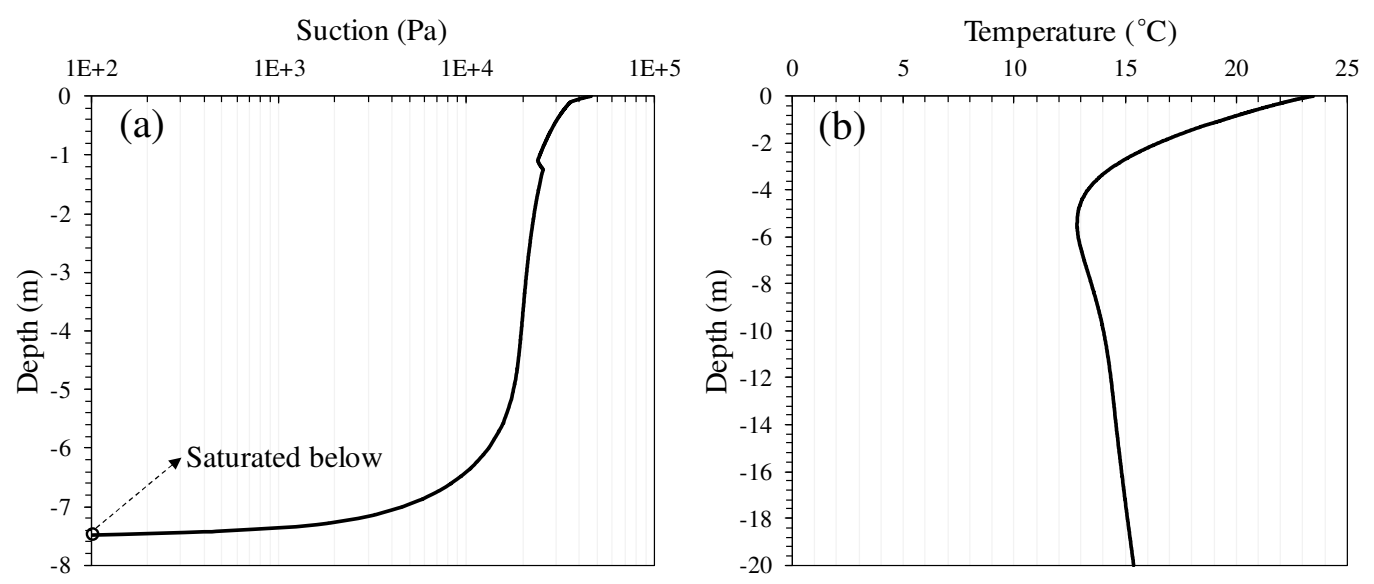

Fig. 4 Initial hydrothermal profiles: (a) suction profile and (b) temperature profile.

3 After the obtention of the initial suction profile, the corresponding initial profiles for the 4 volumetric water content (Fig. 5-a), the soil thermal conductivity (Fig. 5-b) and the soil 5 volumetric heat capacity (Fig. 5-c) are deduced by using the equations 8-10 and their 6 parameters reported in Table 2.
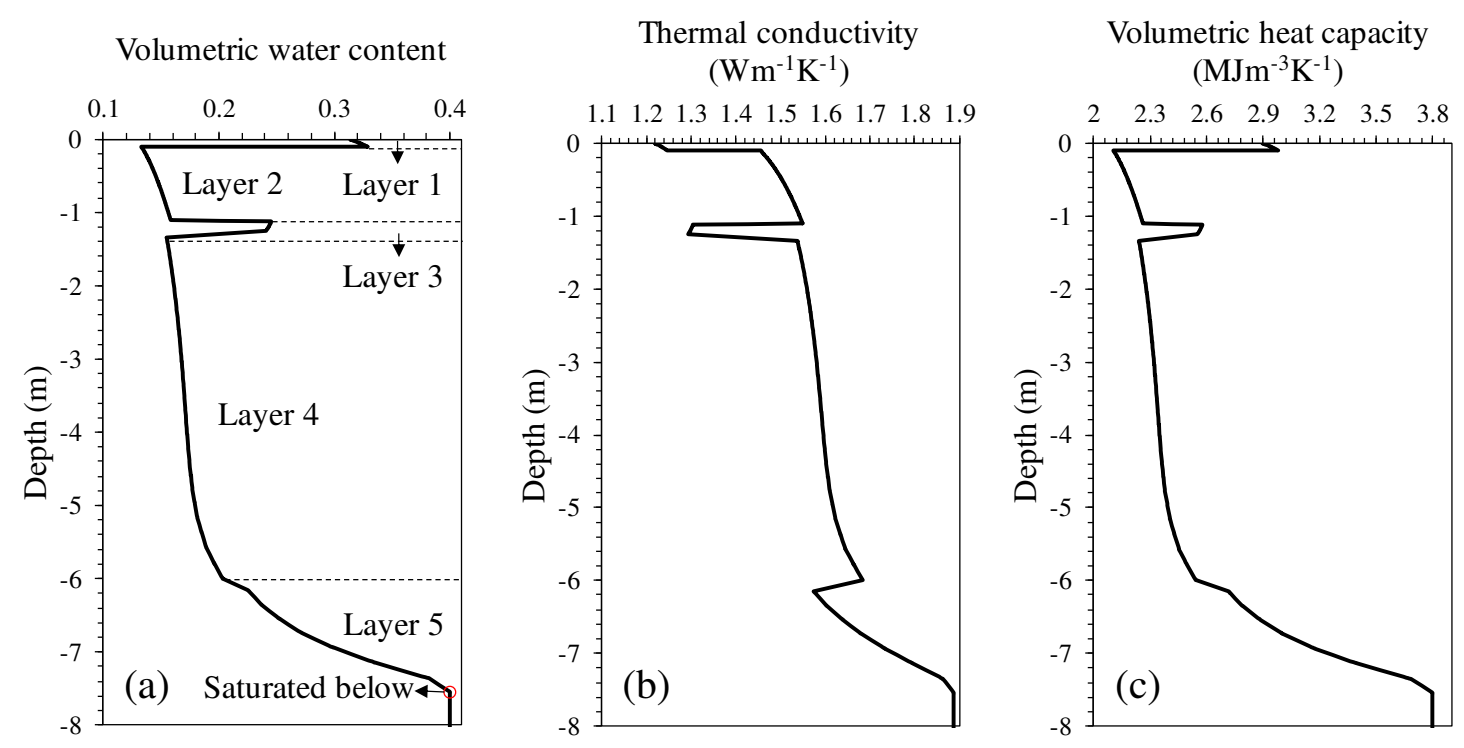

8 Fig. 5 Initial hydrothermal profiles deduced from the initial suction profile: (a) volumetric

9 water content profile; (b) thermal conductivity profile and (c) volumetric heat capacity profile.

10 Fig. 6 shows the comparison of the numerical prediction for a duration of 3 years from July

112014 to July 2017. The Root-Mean-Square Error (RMSE) is determined by: 


$$
\operatorname{RMSE}=\left[\sum_{i=1}^{N}\left(T_{n p, i}-T_{i m, i}\right)^{2} / N\right]^{1 / 2}
$$

2 where $T_{n p}$ is the temperature $\left({ }^{\circ} \mathrm{C}\right)$ from the numerical prediction, $T_{i m}$ is the temperature $\left({ }^{\circ} \mathrm{C}\right)$

3 from the in-situ measurement, $N$ is the number of temperature data. The comparison shows

4 that the numerical framework is capable to predict the soil temperature with the RMSE value 5 of $1.6^{\circ} \mathrm{C}$.

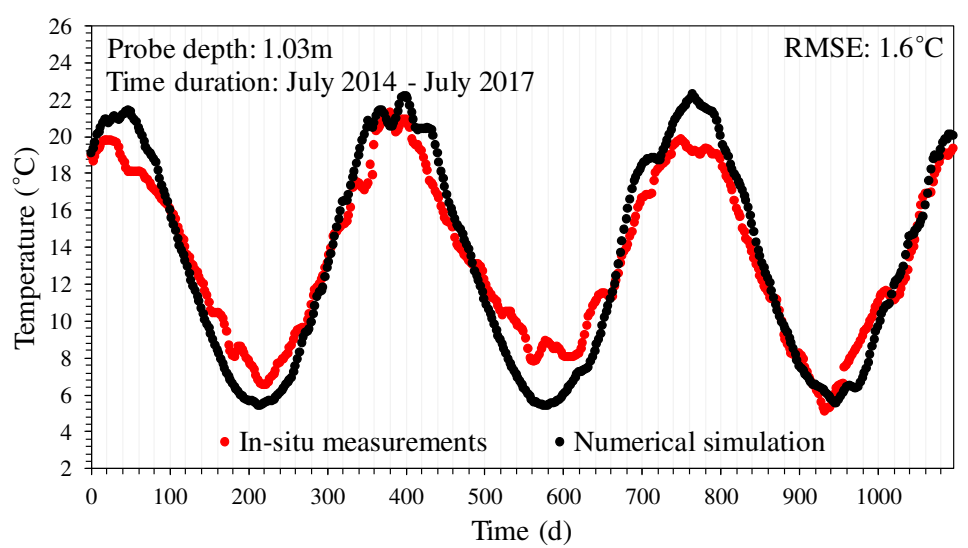

Fig. 6 Comparison between the numerical predictions and the in-situ measurements [43] for 3 years (from July 2014 to July 2017).

\subsection{Validation for the soil-HGHE interaction}

The soil-HGHE interaction of the proposed numerical framework is evaluated by an indoor experiment reported by Yoon et al. [44]. In their work, two experiments are conducted in a sandy box for slinky-type HGHEs with pipe lengths of 24 and $66 \mathrm{~m}$. They have further used a far-infrared radiation heater to maintain constant the indoor temperature. In their experiment, a polybutylene pipe with inner and outer diameters of 16 and $20 \mathrm{~mm}$ is installed at the depth of $0.5 \mathrm{~m}$ in a sand box. The sand box has a length of $5 \mathrm{~m}$, a width of $1 \mathrm{~m}$ and a depth of $1 \mathrm{~m}$. The surrounding dry sand has a thermal conductivity of $0.26 \mathrm{Wm}^{-1} \mathrm{~K}^{-1}$, specific heat capacity of $785 \mathrm{Jkg}^{-1} \mathrm{~K}^{-1}$ and a density of $1.397 \mathrm{gcm}^{-3}$. The carrying fluid is water with a velocity of $0.3921 \mathrm{~ms}^{-1}$ [10]. The initial box temperature is between 17 and $18{ }^{\circ} \mathrm{C}$. The time duration is 
$130 \mathrm{~h}$ for the two experiments. Table 4 summarizes the imposed thermal boundary conditions

2 for this indoor experiment. Water transfer in soil is not considered in this experiment.

3 Table 4 Thermal boundary condition for the indoor experiment reported by Yoon et al. [44]

\begin{tabular}{ll}
\hline Surface or element & Thermal condition, value (unit) \\
\hline Top & Dirichlet, $17.5\left({ }^{\circ} \mathrm{C}\right)$ \\
Lateral & Adiabatic, - \\
Bottom & Adiabatic, - \\
HGHE inlet & Dirichlet, time-varying values [44] (K) \\
\hline
\end{tabular}

4

5 Fig. 7 shows the comparison of the carrying fluid outlet temperatures between the in-situ 6 measurements and the numerical predictions. A good correspondence between the experiment 7 and prediction proves that the established numerical model considers appropriately the soil8 HGHE interaction in its framework.

9
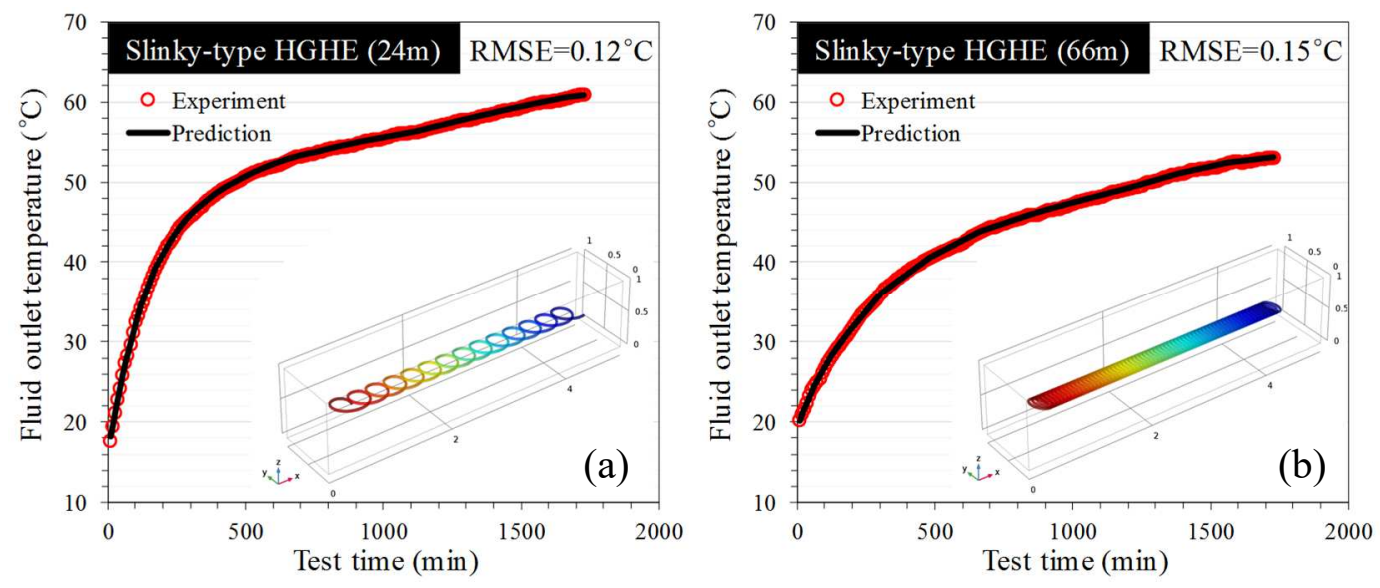

Fig. 7 The comparison between the experiment and the numerical prediction for the carrying fluid outlet temperatures: (a) slinky-type HGHE with a total pipe length of $24 \mathrm{~m}$ and (b) slinky-type HGHE with a total pipe length of $66 \mathrm{~m}$. 


\section{Numerical simulation results with the atmosphere-soil-HGHE}

\section{2 interaction}

3 After validating the numerical framework, the simulation results are subsequently presented

4 in this section considering the atmosphere-soil-HGHE interaction. The same site presented in

5 section 3.1 is investigated in this section. To identify the effect of the atmosphere-soil

6 interaction, another scenario is also tested without considering the atmosphere-soil

7 interaction.

\section{$8 \quad 4.1$ Geometry, mesh and operation options}

9 The studied geometry has a length of $30 \mathrm{~m}$, a width of $12 \mathrm{~m}$ and a height of $20 \mathrm{~m}$. This deep

10 geometry was selected to have no hydrothermal impact of the seasonal metrological condition

11 on the bottom boundary. A slinky-type HGHE with $0.03 \mathrm{~m}$ of inner diameter and $0.036 \mathrm{~m}$ of

12 outer diameter is installed $1 \mathrm{~m}$ below surface, covered with the backfill soil (sandy loam 1

13 presented in section 3.1). The geometry strictly followed the geological profile illustrated in

14 the site description (section 3.1). A swept mesh was deployed to obtain reasonable

15 computation time. It should be noted that the generated meshes are denser in the shallow

16 depths since the shallow ground is more sensitive to hydrothermal fluctuation on the land

17 surface. In addition, the meshes around the HGHE are also denser due to the steep

18 temperature and suction gradients [48]. In total, 75894 meshes were generated for this

19 numerical simulation model. The geometry and its mesh are shown in Fig. 8. 


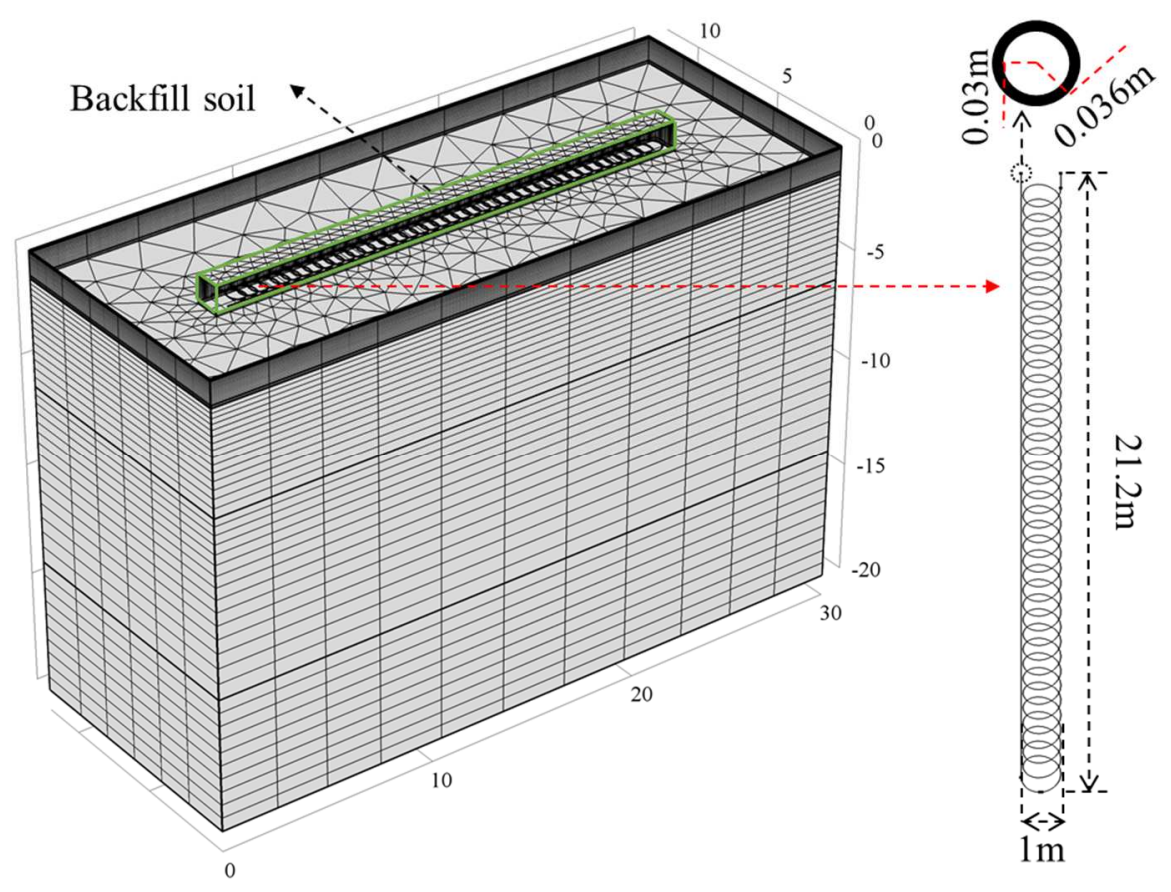

Fig. 8 Geometry and its mesh for the numerical simulations.

3 The meteorological condition corresponds completely to the local condition presented in

4 section 3.1. The same parameters reported in Tables $1 \& 2$ are used for the atmosphere-soil

5 interaction. The same aforementioned cloud cover, wind speed, precipitation and air humidity

6 are also applied (section 3.1). The ambient temperatures for three successive years presented

7 in Fig. 3 are approximated for one year in Fig. 9-a. Fig. 9-b presents the shortwave radiation

8 with time for one year derived from equation 15.
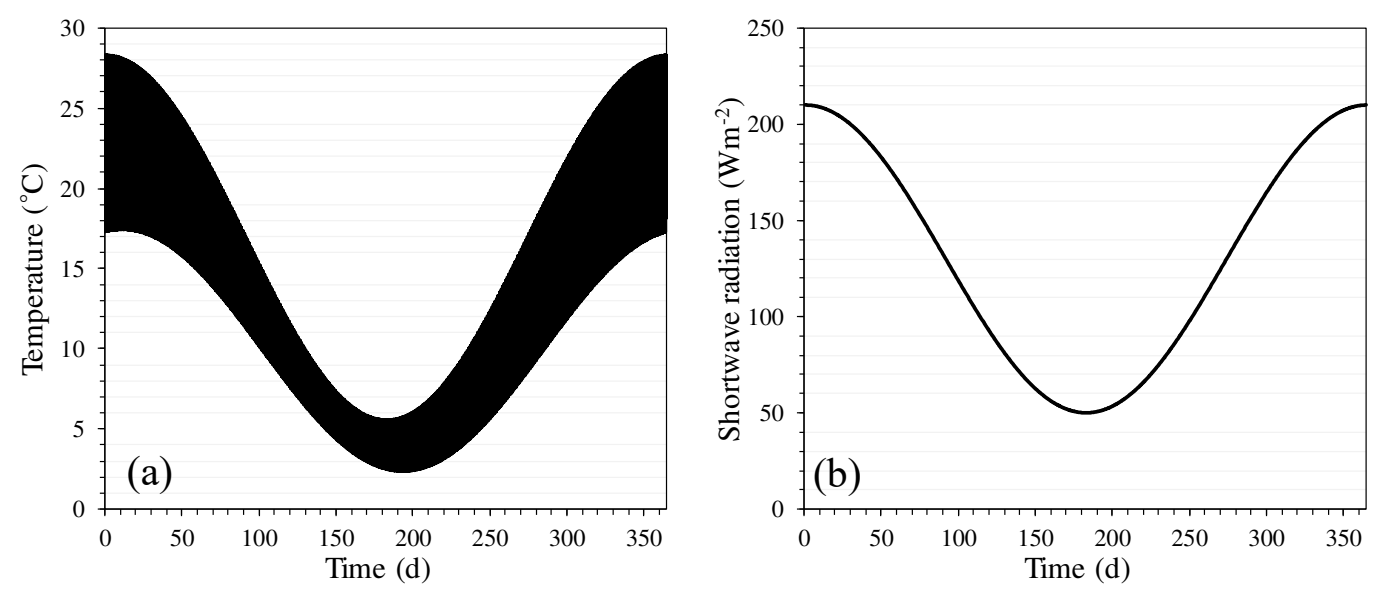

Fig. 9 (a) Ambient temperature fluctuation for one year and (b) shortwave radiation fluctuation for one year. 
1 The pipe is a High-Density Polyethylene (HDPE) pipe with the thermal conductivity of 0.4

$2 \mathrm{Wm}^{-1} \mathrm{~K}^{-1}$. Propylene Glycol (PG) with a volume concentration of $25 \%$ is selected as the

3 carrying fluid. It has a dynamic viscosity of 0.0055 Pas, a density of $1026 \mathrm{kgm}^{-3}$, a thermal

4 conductivity of $0.45 \mathrm{Wm}^{-1} \mathrm{~K}^{-1}$ and a specific heat capacity of $3974 \mathrm{Jkg}^{-1} \mathrm{~K}^{-1}$ [49]. The carrying

5 fluid velocity is $0.5 \mathrm{~ms}^{-1}$ during the operation period.

6 A heating scenario is considered in our simulations according to the local climate condition.

7 The HGHE works from the $100^{\text {th }}$ day to the $265^{\text {th }}$ day in a year. A seasonal heat extraction rate

8 varying from 10 to $40 \mathrm{Wm}^{-1}$ is applied to the HGHE during its operation period (Fig. 10). The

9 time step for the numerical simulation model is 0.5 day.

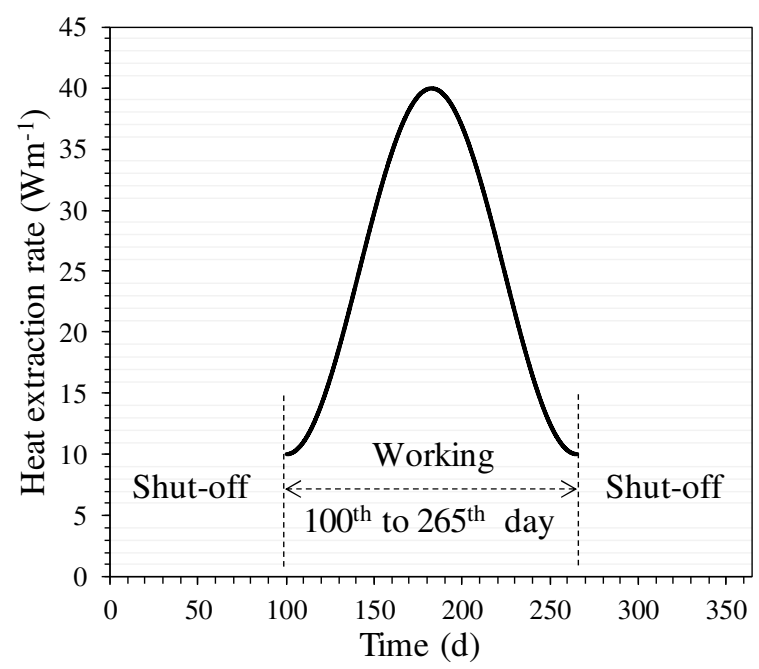

11 Fig. 10 Heat extraction rate $\left(\mathrm{Wm}^{-1}\right)$ during the operation period of the HGHE.

\subsection{Annual fluctuation of the hydrothermal properties and the HGHE} performance

14 To visualize the spatial and temporal hydrothermal fluctuation in soil, five horizontal line 15 probes are positioned at five different depths: surface (or zero), 1, 2.5, 5 and $10 \mathrm{~m}$ (Fig. 11). 16 All the probes are installed in the same vertical plane through the center of the HGHE. 
Instrumented 5 horizontal line probes in the model

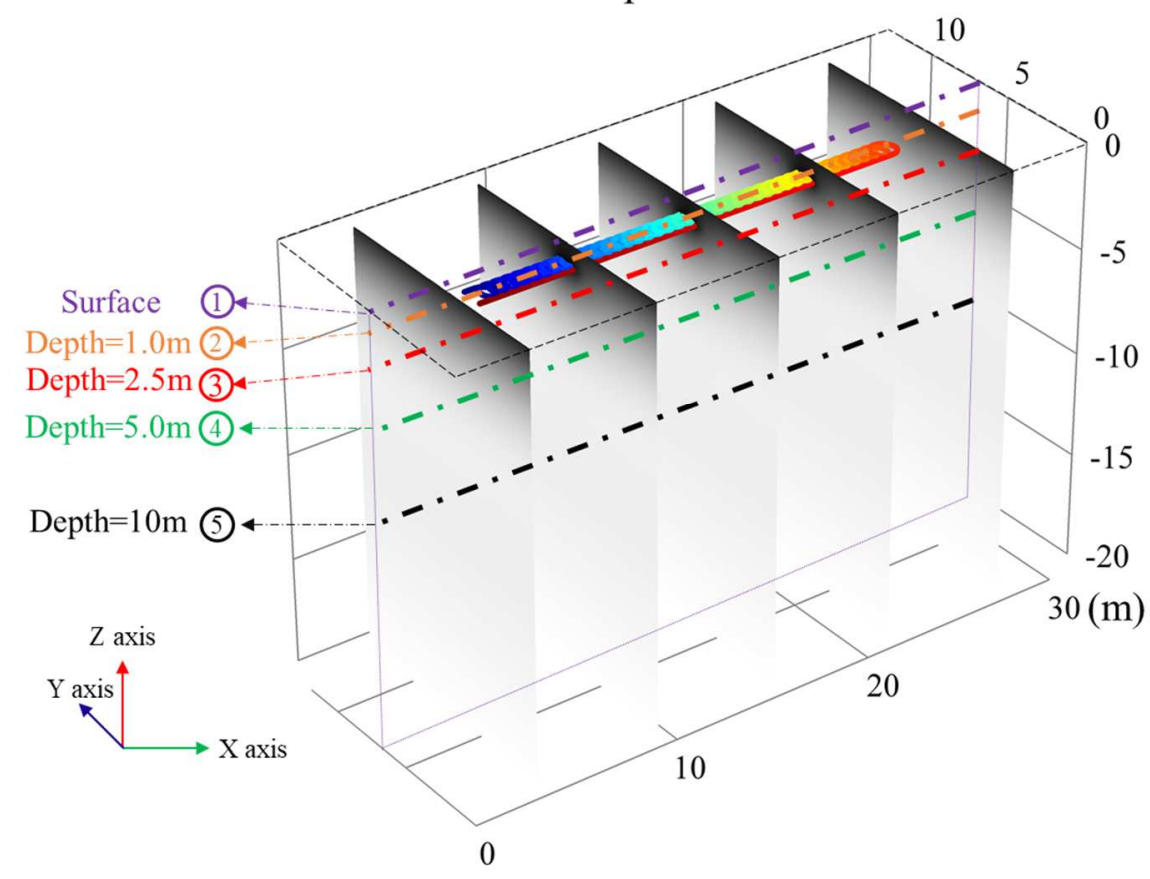

Fig. 11 Five horizontal line probes positioned at different depths: $0,1,2.5,5$ and $10 \mathrm{~m}$.

3 Fig. 12 shows the variation of the volumetric water content (Fig. 12-a) and the temperature

4 (Fig. 12-b) in the 5 probes at different times (99, 130, 182.5, 200 and 260 days). Fig. 12-a

5 shows that the volumetric water content has less fluctuation with time as the depth increases.

6 The fluctuation of volumetric water content becomes negligible as the depth is higher than 5

$7 \mathrm{~m}$. Due to the existence of the backfill soil, the volumetric water content differs spatially

8 along the HGHE, especially on the land surface. The same effect can be observed at the depth

9 of $1.0 \mathrm{~m}$, while it disappears at a depth higher than $2.5 \mathrm{~m}$. Fig. 12-b shows that the seasonal

10 temperature fluctuation is obvious in the shallow depths, while it almost vanishes when the

11 depth reaches $10 \mathrm{~m}$. During the service period, the temperature around the HGHE decreases.

12 The line probe 2 is the most influenced probe because it is positioned at the same depth of the

13 HGHE. The effect is also evident at the depth of $2.5 \mathrm{~m}$. The surface temperature has also been

14 influenced during the service period of the HGHE, and a difference of $0.6{ }^{\circ} \mathrm{C}$ is observed after

15200 days. The HGHE operation influences less the subsurface temperature when the distance 
1 from the HGHE becomes larger. The soil temperature is negligibly influenced by the HGHE

2 at the depth of $5 \mathrm{~m}$, and this effect can be considered absent at the depth of $10 \mathrm{~m}$.
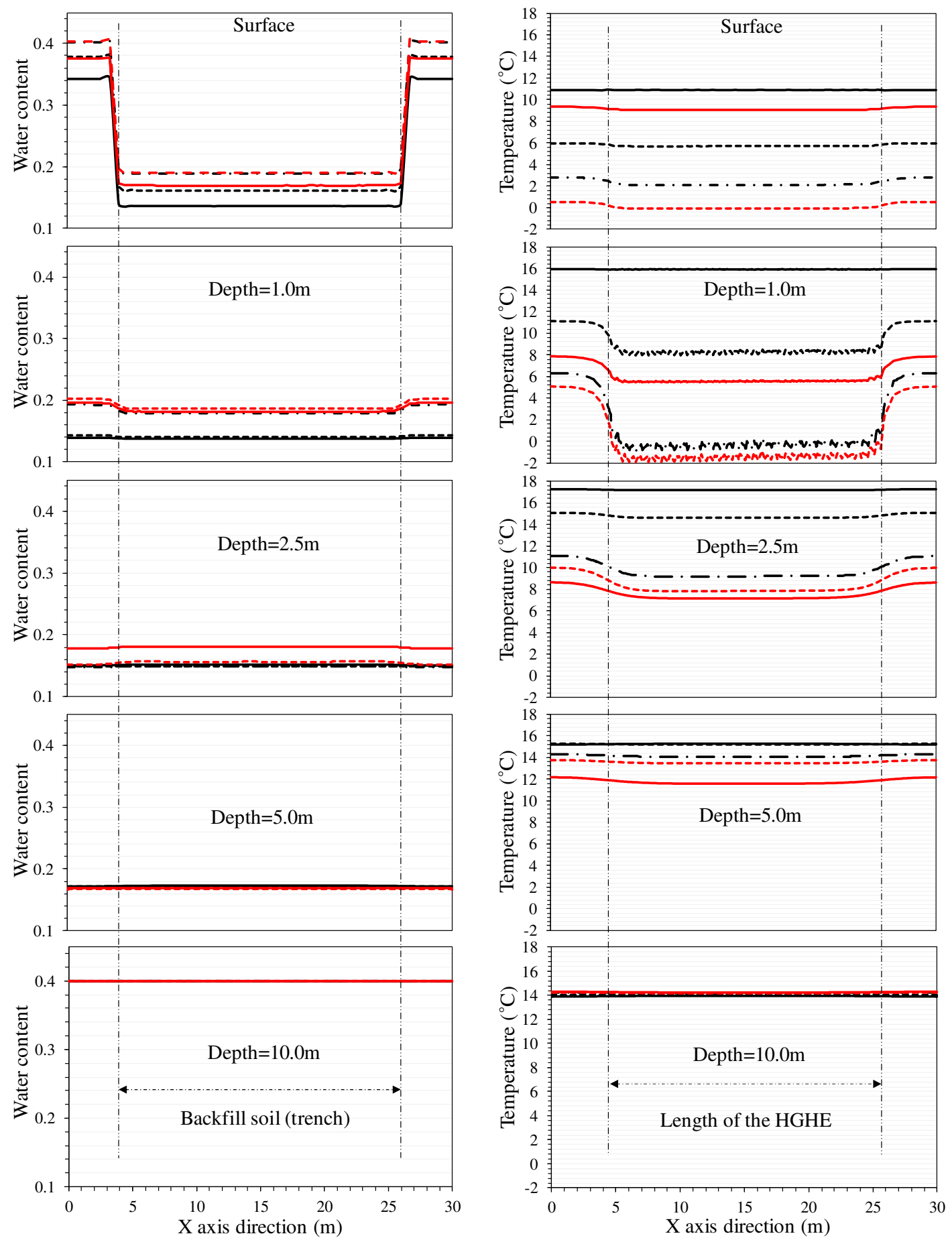

Fig. 12 Volumetric water content and temperature fluctuation at 5 times of a year for the five 
1 horizontal probes: (a) volumetric water content fluctuation and (b) temperature fluctuation.

2 The HGHE operation affects the land surface temperature and consequently its ground heat

3 flux. To visualize this effect, the heat flux fluctuation is presented along the surface line probe

4 (probe 1) in Fig. 13. The ground heat flux remains unchanged during the first 99 days. When

5 the HGHE starts working, the ground heat flux at the zone affected by the HGHE is higher

6 than the non-affected zone due to the heat extraction during the heating season. Specifically,

7 the ground heat fluxes at the zone affected by the HGHE are 2.7, 9.2, 8.5 and 2.7 $\mathrm{Wm}^{-2}$ higher

8 than the unaffected zone on the days $130,182.5,200$ and 260 , respectively.
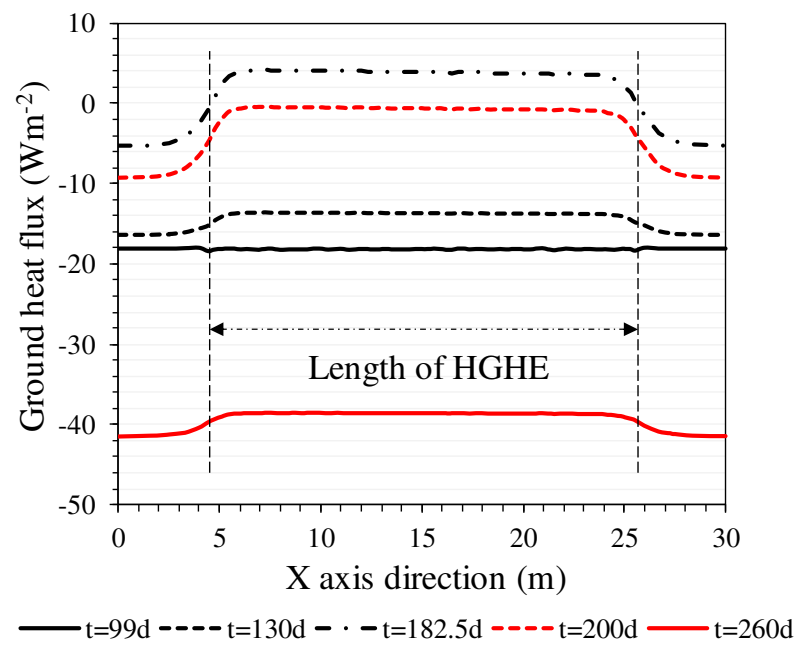

Fig. 13 Ground heat flux fluctuation detected by the horizontal line probe 1 on the land surface.

During the service time of the HGHE, the Total Extracted Energy (TEE) can be obtained by the following equation:

$$
\mathrm{TEE}=\int A \rho_{f} u_{f} C_{p-f}\left(T_{\text {out }}-T_{\text {in }}\right) d t
$$

where $T_{\text {in }}$ is the fluid inlet temperature $\left({ }^{\circ} \mathrm{C}\right)$.

Fig. 14 shows the TEE and the fluid outlet temperature of the HGHE during its annual working period. The figure shows that the installed HGHE can extract 7.52 GJ of energy after 
11 year. The annual average fluid outlet temperature can be obtained as $3.41{ }^{\circ} \mathrm{C}$ in the

2 operation period. Generally, the fluid outlet temperature decreases continuously until the day

3 201, and then it increases until it stops working. The phenomenon illustrates that a time lag of

$4 \quad 18.5$ days exists between the peak heat load $(t=182.5$ d, Fig. 10) and the lowest ground 5 temperature $(\mathrm{t}=201 \mathrm{~d})$ surrounding the HGHE.
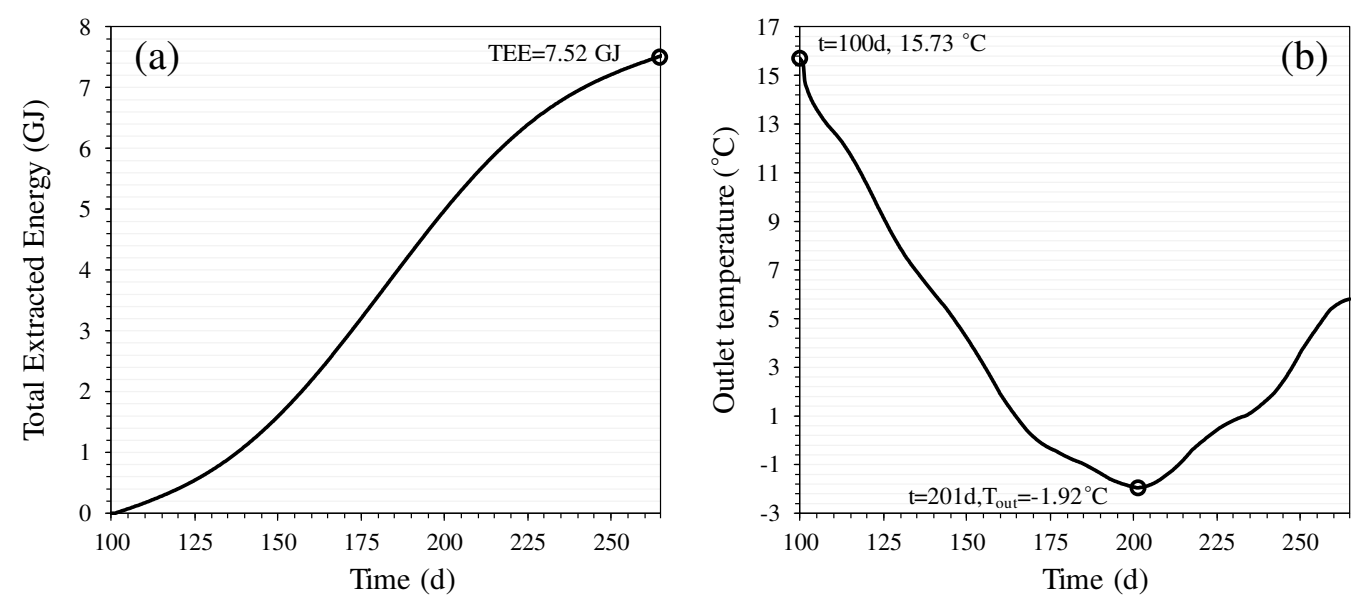

Fig. 14 The extracted energy and the fluid outlet temperature with time during the service period of the HGHE: (a) extracted energy with time and (b) fluid outlet temperature with time.

4.3 The comparison of the HGHE performance at different depths with and

\section{without considering the atmosphere-soil interaction}

As shown in Fig. 12-b and Fig. 13, the HGHE operation influences simultaneously the land surface temperature and the ground heat flux. To identify this influence on the outlet temperature of the HGHE, another scenario is tested in this part without considering the atmosphere-soil interaction. Compared to the boundary conditions with the atmosphere-soil interaction (Table 3), the popular Dirichlet boundary condition on the land surface is considered in this new scenario (Table 5), where the atmosphere temperature (equation 14) is imposed to the land surface and the operation of the HGHE has no effect on the land surface 
1 temperature and heat flux. In both scenarios, the energy extraction rate (Fig. 10) and the TEE

2 (Fig. 14-b) are kept the same.

3 Table 5 Hydrothermal boundary conditions for the scenario without the atmosphere-soil interaction

\begin{tabular}{lll}
\hline Surface & Hydraulic condition, value (unit) & Thermal condition, value (unit) \\
\hline Top & Neumann, equation $5\left(\mathrm{~ms}^{-1}\right)$ & Dirichlet, equation $14\left({ }^{\circ} \mathrm{C}\right)$ \\
Lateral & Adiabatic, - & Adiabatic, - \\
\multirow{2}{*}{ Bottom } & $\begin{array}{l}\text { Dirichlet, model height }- \text { groundwater } \\
\text { level }(\mathrm{m})\end{array}$ & $\begin{array}{l}\text { Neumann, bottom temperature gradient } \times \\
\text { bottom soil thermal conductivity }\left(\mathrm{Wm}^{-2}\right)\end{array}$ \\
\hline
\end{tabular}

5

6 Fig. 15 shows the fluid outlet temperatures obtained in both scenarios for the HGHE installed

7 at the depths of $0.5,1.0,1.5$ and $2 \mathrm{~m}$. The figure shows that the non-consideration of the

8 atmosphere-soil interaction overestimates the fluid outlet temperatures, and this

9 overestimation declines with the increase of the installation depth. When the HGHE is

10 installed at a larger depth, the fluctuation of its outlet temperatures is less significant in both

11 scenarios.
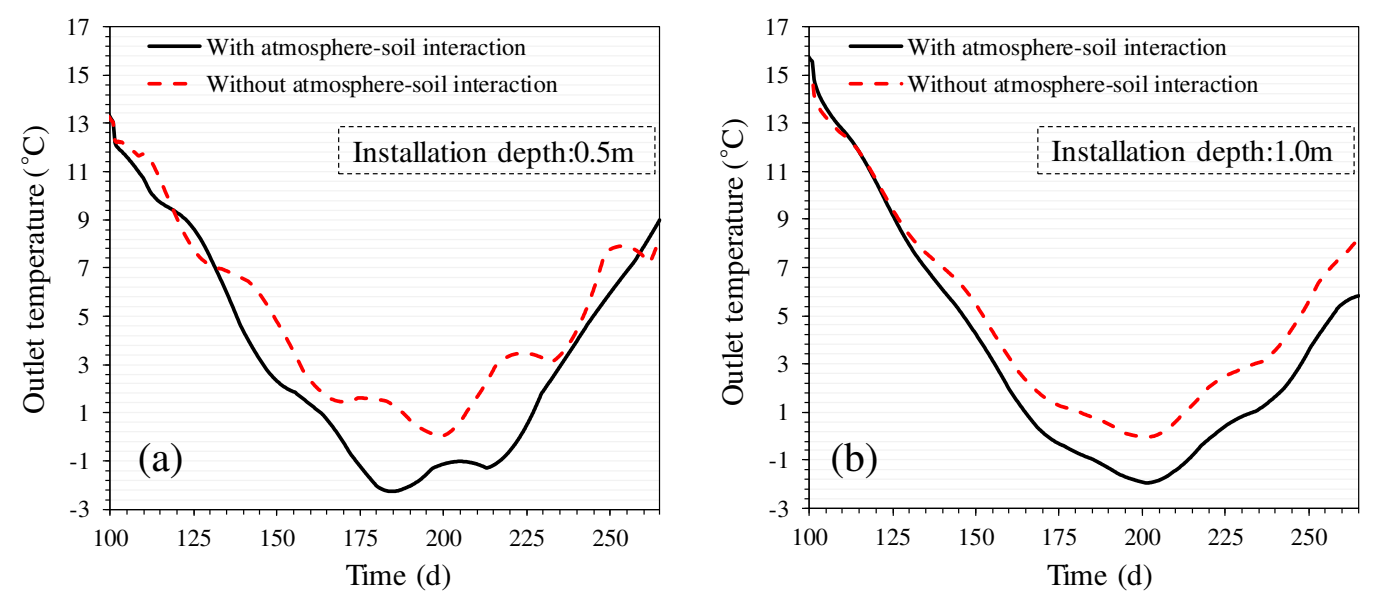

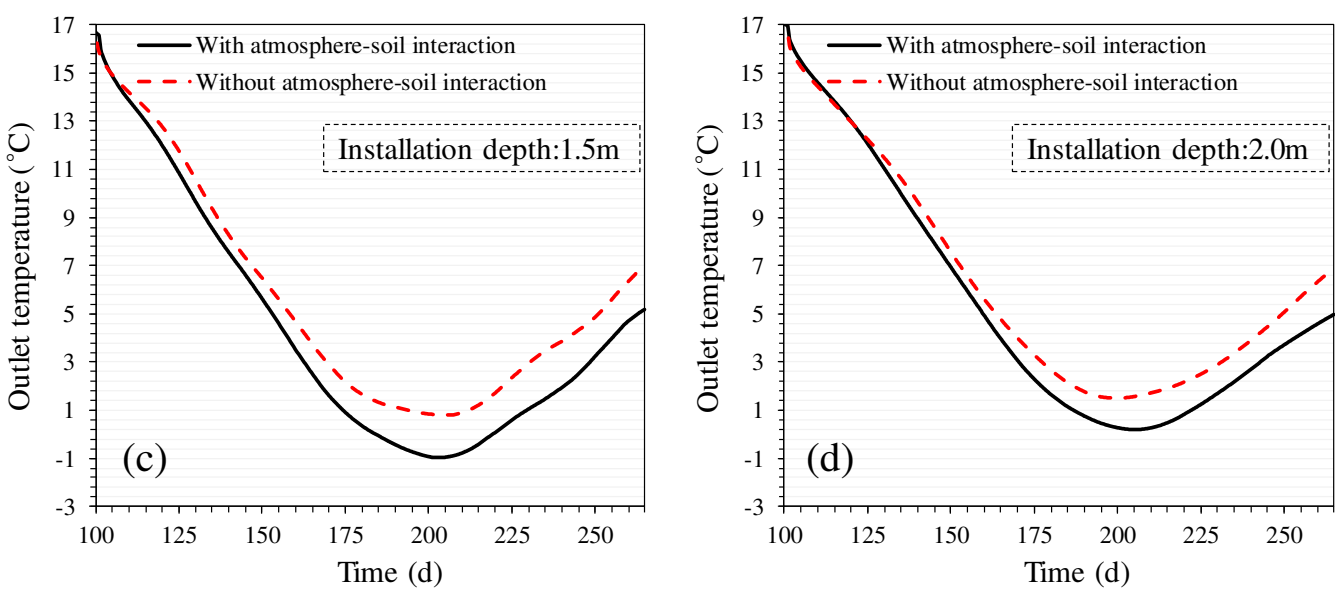

Fig. 15 Carrying fluid outlet temperatures with time regarding with and without the atmosphere-soil interaction for the HGHE installed at 4 different depths: (a) $0.5 \mathrm{~m}$; (b) $1 \mathrm{~m}$; (c) $1.5 \mathrm{~m}$ and (d) $2 \mathrm{~m}$.

5 Fig. 16 compares the annual average fluid outlet temperatures of these 2 scenarios. Generally, 6 a deep installation improves the fluid outlet temperature. When the installation depth 7 increases from 0.5 to $2 \mathrm{~m}$, the annual average fluid outlet temperatures increase $61.11 \%$ and $827.56 \%$ correspondingly for the scenarios with and without considering the atmosphere-soil 9 interaction. The increase of the installation depth from 0.5 to $1 \mathrm{~m}$ has an insignificant effect 10 on the annual average fluid outlet temperatures in both scenarios.

11 Furthermore, the results confirm the significant influence of the atmosphere-soil interaction in

12 the HGHE simulations. The annual average fluid outlet temperatures are highly overestimated 13 when the interaction is absent in the calculations especially if the HGHE is installed close to 14 the land surface. The overestimation caused by the non-consideration of the atmosphere-soil 15 interaction decreases with the increase of the installation depth. In general, the overestimation decreases from $47.99 \%$ to $17.16 \%$ as the installation depth increases from 0.5 to $2 \mathrm{~m}$. 


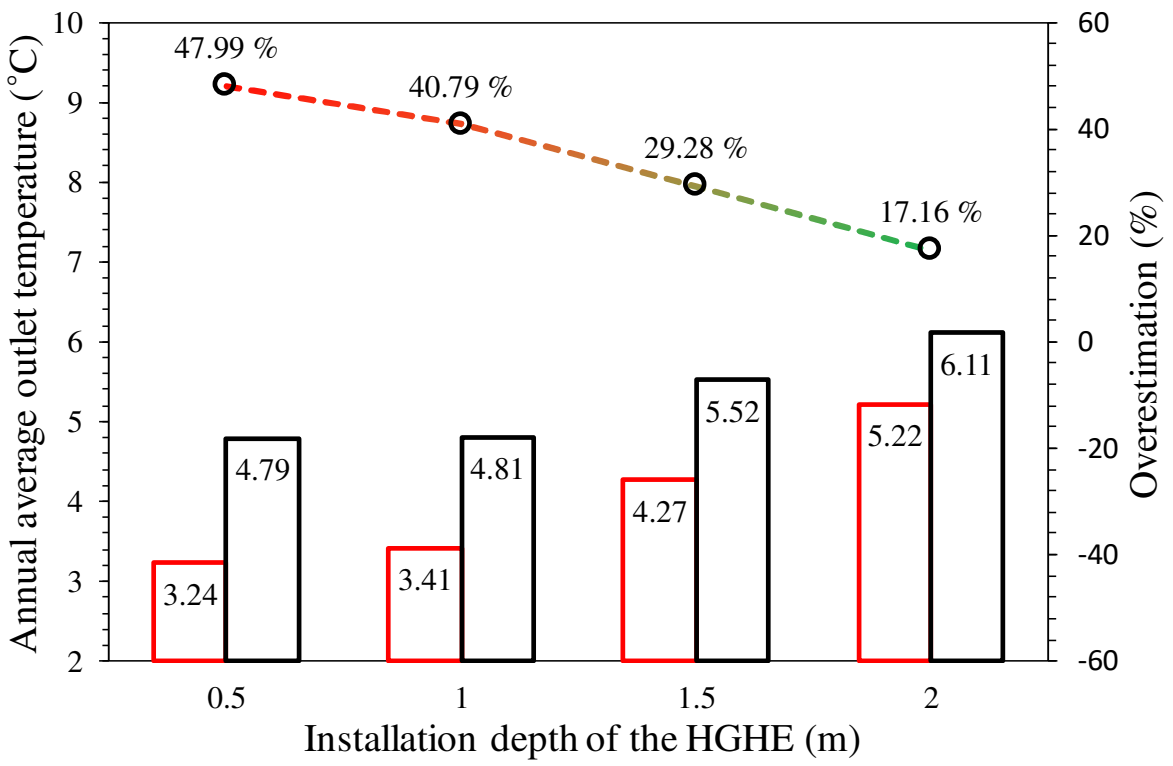

Fig. 16 Comparison between the annual average fluid outlet temperatures with and without the atmosphere-soil interaction.

4 As it has been reported regularly in the literature [49,50,51], the fluid outlet temperature from

5 the HGHE is linear to the heat pump performance, and consequently the HGHE performance.

6 The higher the fluid outlet temperature in the heating scenario, the higher the HGHE

7 performance. Therefore, the same conclusions observed for the fluid outlet temperature can be 8 generalized for the HGHE performance.

\section{Conclusion}

10 This paper has evaluated the outlet temperatures of a slinky-type HGHE installed in a multi-

11 layered soil field by considering the local metrological and geological conditions.

12 The numerical simulations were firstly validated by the measured data from literature. The

13 results showed the good capacity of the proposed framework to consider the atmosphere-soil-

14 HGHE interaction.

15 The yearly variations of the in-situ hydrothermal properties were investigated on the 
1 horizontal line probes positioned at 5 different depths. The results showed that the soil surface

2 temperature and the ground heat flux were obviously affected during the service period of the

3 HGHE. The affected surface zone had lower temperatures than the unaffected zone while a

4 higher ground heat flux was observed in this zone. Subsequently, the annual average fluid

5 outlet temperature for the in-situ site was estimated $3.41^{\circ} \mathrm{C}$ under the seasonal heat load.

6 Moreover, the fluid outlet temperatures were further compared for the HGHE installed at 4

7 different depths with and without considering the atmosphere-soil interaction. Generally, a 8 deep installation increased the fluid outlet temperatures; however, this increase was 9 insignificant when the installation depth increased from 0.5 to $1 \mathrm{~m}$. The results also showed

10 the importance of considering atmosphere-soil interaction in the numerical calculations. The 11 annual average fluid outlet temperature was overestimated when the atmosphere-soil 12 interaction was not considered. This overestimation decreased from $47.99 \%$ to $17.16 \%$ as the 13 installation depth of the HGHE increased from 0.5 to $2 \mathrm{~m}$.

14 These findings are important in the design stage of the HGHE engineering. The effect of the 15 atmosphere-soil interaction on the HGHE performance is a crucial factor. This effect is more 16 /less intensified when the installation depth decreased/increased. A deep installation of the 17 HGHE improves the system performance, but it increases the trench digging cost. An 18 appropriate cost/performance ratio may be the best practical solution in HGHE engineering.

\section{Acknowledgment}

20 The authors are grateful to China Scholarship Council (CSC) for providing the financial 21 support.

\section{Reference}

23 [1] Shortall R, Davidsdottir B, Axelsson G. Geothermal energy for sustainable development: 24 A review of sustainability impacts and assessment frameworks. Renewable and 
Sustainable $\quad$ Energy $\quad$ Reviews $\quad 2015 ; \quad 44: \quad 391-406$. https://doi.org/10.1016/j.rser.2014.12.020.

[2] Sangi R, Müller D. Dynamic modelling and simulation of a slinky-coil horizontal ground heat exchanger using Modelica. Journal of Building Engineering 2018; https://doi.org/10.1016/j.jobe.2018.01.005.

[3] Lee C, You J, Park H. In-situ response test of various borehole depths and heat injection rates at standing column well geothermal heat exchanger systems. Energy \& Buildings; 2018; 172: 201-208. https://doi.org/10.1016/j.enbuild.2018.05.009.

[4] Florides G, Kalogirou S. Ground heat exchangers-A review of systems, models and applications. Renewable Energy 2007. 32: 2461-2478. https://doi.org/10.1016/j.renene.2006.12.014.

[5] Adamovsky D, Neuberger P, Adamovsky R. Changes in energy and temperature in the ground mass with horizontal heat exchangers-The energy source for heat pumps. Energy and Buildings 2015. 92: 107-115. https://doi.org/10.1016/j.enbuild.2015.01.052.

[6] Self S, Reddy B, Rosen M. Geothermal heat pump systems: Status review and comparison with other heating options. Applied Energy 2013; 101: 341-348. https://doi.org/10.1016/j.apenergy.2012.01.048.

[7] Xiong Z, Fisher D, Spitler J. Development and validation of a Slinky ${ }^{\mathrm{TM}}$ ground heat exchanger model. Applied Energy 2015; 141: 57-69. https://doi.org/10.1016/j.apenergy.2014.11.058.

[8] Al-Ameen Y, Ianakiev A, Evans R. Recycling construction and industrial landfill waste material for backfill in horizontal ground heat exchanger systems. Energy 2018; 151: 556-568. https://doi.org/10.1016/j.energy.2018.03.095.

[9] Gonzalez R, Verhoef A, Vidale P, Main B, Gan G, Wu Y. Interactions between the physical soil environment and a horizontal ground coupled heat pump, for a domestic site in the UK. Renewable Energy 44 (2012) 141-153. https://doi.org/10.1016/j.renene.2012.01.080.

[10]Habibi M, Hakkaki-Fard A. Evaluation and improvement of the thermal performance of different types of horizontal ground heat exchangers based on techno-economic analysis. Energy Conversion and Management 2018; 171: 1177-1192. https://doi.org/10.1016/j.enconman.2018.06.070.

[11]Kim J, Lee S, Yoon S, Go G. Thermal performance evaluation and parametric study of a horizontal ground heat exchanger. Geothermics 2016; 60: 134-143. https://doi.org/10.1016/j.geothermics.2015.12.009.

[12]Congedo P, Colangelo G, Starace G. CFD simulations of horizontal ground heat exchangers: A comparison among different configurations. Applied Thermal Engineering 33-34 (2012) 24-32. https://doi.org/10.1016/j.applthermaleng.2011.09.005.

[13]Gan G. Dynamic thermal modelling of horizontal ground-source heat pumps. International Journal of Low-Carbon Technologies 2013; 8: 95-105. doi:10.1093/ijlct/ctt012.

[14]Go G, Lee S, Yoon S, Kim M. Optimum design of horizontal ground-coupled heat pump 
systems using spiral-coil-loop heat exchangers. Applied Energy 2016; 162: 330-345. https://doi.org/10.1016/j.apenergy.2015.10.113.

[15] Selamat S, Miyara A, Kariya K. Numerical study of horizontal ground heat exchangers for design optimization. Renewable Energy 2016; 95: 561-573. http://dx.doi.org/10.1016/j.renene.2016.04.042.

[16]Li C, Mao J, Zhang H, Xing Z, Li Y, Zhou J. Numerical simulation of horizontal spiralcoil ground source heat pump system: Sensitivity analysis and operation characteristics. $\begin{array}{lllll}\text { Applied Thermal } & \text { Engineering } & \text { 2017; } & \text { 110: 435. }\end{array}$ http://dx.doi.org/10.1016/j.applthermaleng.2016.08.134.

[17]Gao Y, Fan R, Li H, Liu R, Lin X, Guo H, Gao Y. Thermal performance improvement of a horizontal ground-coupled heat exchanger by rainwater harvest. Energy and Buildings 2016; 110: 302-313. http://dx.doi.org/10.1016/j.enbuild.2015.10.030.

[18]Jeon J, Lee S, Kim M, Yoon S. Suggestion of a Scale Factor to Design Spiral-Coil-Type Horizontal Ground Heat Exchangers. Energies 2018; 11:2736. doi:10.3390/en11102736.

[19]Kim M, Lee S, Yoon S, Jeon J. Evaluation of geometric factors influencing thermal performance of horizontal spiral-coil ground heat exchangers. Applied Thermal Engineering 2018; 144: 788-796. https://doi.org/10.1016/j.applthermaleng.2018.08.084.

[20]Han C, Ellett K, Naylor S, Yu X. Influence of local geological data on the performance of horizontal ground-coupled heat pump system integrated with building thermal loads. Renewable Energy 2017; 113: 1046-1055. https://doi.org/10.1016/j.renene.2017.06.025.

[21] Pu L, Xu L, Qi D, Li Y. Structure optimization for horizontal ground heat exchanger. Applied Thermal Engineering 2018; 136: 131-140. https://doi.org/10.1016/j.applthermaleng.2018.02.101.

[22]Wu Y, Gan G, Verhoef A, Vidale P, Gonzalez R. Experimental measurement and numerical simulation of horizontal-coupled slinky ground source heat exchangers. $\begin{array}{lllll}\text { Applied } & \text { Thermal } & \text { Engineering } & 30 & \text { (2010) }\end{array}$ https://doi.org/10.1016/j.applthermaleng.2010.07.008.

[23] Naylor S, Ellett K, Gustin A. Spatiotemporal variability of ground thermal properties in glacial sediments and implications for horizontal ground heat exchanger design. Renewable Energy 2015; 81: 21-30. https://doi.org/10.1016/j.renene.2015.03.006.

[24]Gan G. Dynamic thermal performance of horizontal ground source heat pumps - The impact of coupled heat and moisture transfer. Energy 2018; 152: 877-887. https://doi.org/10.1016/j.energy.2018.04.008.

[25]Fujii H, Okubo H, Cho, K. Ohyama. Field tests of horizontal ground heat exchangers, in: Proceedings of the 2010 World Geothermal Congress, Bali, Indonesia, April 25-29, 2010, Paper No. 2904, p. 6.

[26]Chalhoub M, Bernier M, Coquet Y, Philippe M. A simple heat and moisture transfer model to predict ground temperature for shallow ground heat exchangers. Renewable Energy 2017; 103: 295-307. http://dx.doi.org/10.1016/j.renene.2016.11.027.

[27]Cole R. The longwave radiation incident upon the external surface of buildings. Building Services Engineers 1976; 44: 195-206. 
[28]Choi W, Ooka R, Nam Y. Impact of long-term operation of ground-source heat pump on subsurface thermal state in urban areas. Sustainable Cities and Society 2018; 38: 429-439. https://doi.org/10.1016/j.scs.2017.12.036.

[29]Allen R. A Penman for all seasons. J. Irrig. Drain. Eng. 1986; 112: 348-368.

[30]Turc L. Le Bilan d'eau des sols : relations entre les précipitations, l'évaporation et l'écoulement. Ann. Agron. 1954; 5: 491-569.

[31]Pike J. The estimation of annual runoff from meteorological data in a tropical climate. Journal of Hydrology 1964. 2: 116-123.

[32]Chen X, Buchberger S. Exploring the relationships between warm-season precipitation, potential evaporation, and "apparent" potential evaporation at site scale. Hydrol. Earth Syst. Sci. 2018, 22: 4535-4545. https://doi.org/10.5194/hess-22-4535-2018.

[33] Gerrits A, Savenije H, Veling E, Pfister L. Analytical derivation of the Budyko curve based on rainfall characteristics and a simple evaporation model. Water Resource Research 2009, doi:10.1029/2008WR007308.

[34]Monteith J. Evaporation and environment. Symp. Soc. Exp. Biol 1965; 19: 205-234.

[35]Allen R, Jensen M, Wright J, Burman R. Operational estimates of evapotranspiration. Agron. J. 1989; 81: 650-662.

[36]Dietrich O, Fahle M, Seyfarth M. Behavior of water balance components at sites with shallow groundwater tables: Possibilities and limitations of their simulation using different ways to control weighable groundwater lysimeters. Agricultural Water Management 2016; 163: 75-89. https://doi.org/10.1016/j.agwat.2015.09.005.

[37] Mualem Y. A new model for predicting the hydraulic conductivity of unsaturated porous media. Water Resour. Res. 1976; 12(3): 513-522. https://doi.org/10.1029/WR012i003p00513.

[38] van Genuchten MT. A closed-form equation for predicting the hydraulic conductivity of unsaturated soils. Soil Sci Soc Am J 1980; 44: 892-898. doi: 10.2136/sssaj1980.03615995004400050002x.

[39] Nowamooz H, Nikoo-Sokhan S, Lin J, Chazallon C. Finite difference modeling of heat distribution in multilayer soils with time-spatial hydrothermal properties. Renewable Energy 2015; 76: 7-15. https://doi.org/10.1016/j.renene.2014.11.008.

[40]Nikoosokhan S, Nowamooz H, Chazallon C. Effect of texture, water content and dry density on the soil thermal conductivity. International Journal of Geomechanics and Geoengineering 2016. 11(2): 149-158. https://doi.org/10.1080/17486025.2015.1048313.

[41]Tang F, Nowamooz H. Hydro-thermal properties of the unsaturated soil. Conference: Civil Infrastructures Confronting Severe Weathers and Climate Changes Conference 2019; DOI: 10.1007/978-3-319-95744-9_2.

[42]Tang F, Nowamooz H. Long-term performance of a shallow borehole heat exchanger installed in a geothermal field of Alsace region. Renewable Energy 2018; 128: 210-222. https://doi.org/10.1016/j.renene.2018.05.073.

[43]Lin J, Nowamooz H, Braymand S, Wolff P, Fond C. Impact of soil moisture on the long- 
term energy performance of an earth-air heat exchanger system. Renewable Energy 2018; 1-12. https://doi.org/10.1016/j.renene.2018.06.106.

[44] Yoon S, Lee S, Go G. Evaluation of thermal efficiency in different types of horizontal ground heat exchangers. Energy and Buildings 2015; 105: 100-105. http://dx.doi.org/10.1016/j.enbuild.2015.07.054.

[45]Tang F, Nowamooz H. Factors influencing the performance of shallow Borehole Heat Exchanger. Energy Conversion and Management 2019; 181:571-583. https://doi.org/10.1016/j.enconman.2018.12.044.

[46]Cuny M, Lin J, Siroux M, Fond C. Simplification of boundary conditions of the modeling of shallow geothermal systems. French Thermal Congress 2015; La Rochelle, France.

[47]Baillieuxm P, Schill E, Edel J, Mauri G. Localization of temperature anomalies in the Upper Rhine Graben: insights from geophysics and neotectonic activity. International Geology Review 2013; 55: 1744-1762. https://doi.org/10.1080/00206814.2013.794914.

[48]Choi W, Ooka R. Effect of disturbance on thermal response test, part 2: Numerical study of applicability and limitation of infinite line source model for interpretation under disturbance from outdoor environment. Renewable Energy 2016; 85: 1090-1105. http://dx.doi.org/10.1016/j.renene.2015.07.049.

[49]Casasso A, Sethi R. Efficiency of closed loop geothermal heat pumps: a sensitivity analysis. Renew Energy 2014; 62:737-746. https://doi.org/10.1016/j.renene.2013.08.019.

[50]Hein P, Kolditz O, Görke UJ, Bucher A, Shao H. A numerical study on the sustainability and efficiency of borehole heat exchanger coupled ground source heat pump systems.

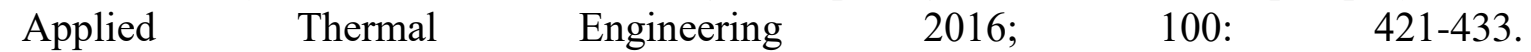
https://doi.org/10.1016/j.applthermaleng.2016.02.039.

[51] Shao H, Hein P, Sachse A, Kolditz O. Geoenergy Modeling II: Shallow Geothermal Systems. Springer briefs in energy: computational modeling of energy systems; 2016. https://doi.org/10.1007/978-3-319-45057-5. 